\title{
Trade union membership retention and workplace representation in Europe
}

Jeremy Waddington

Working Paper 2014.10

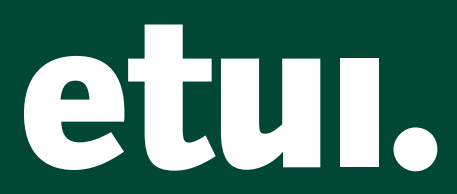




\section{Trade union membership retention and workplace representation in Europe \\ Questions on the renewal of trade union organisation}

Jeremy Waddington

Working Paper 2014.10

European Trade Union Institute 
Jeremy Waddington is Professor of Industrial Relations at the University of Manchester and the Project Coordinator at the European Trade Union Institute, Brussels. Contact: Jeremy.Waddington@manchester.ac.uk

The author thanks Maria Jepsen and Kurt Vandaele for their helpful comments on earlier drafts of this Working Paper.

This Working Paper is a revised version of an article to be published in the European Journal of Industrial Relations.

Brussels, 2014

Publisher: ETUI aisbl, Brussels

All rights reserved

Print: ETUI Printshop, Brussels

D/2014/10.574/33

ISBN: 1994-4446 (print version)

ISBN: 1994-4454 (electronic version)

The ETUI is financially supported by the European Union. The European Union is not responsible for any use made of the information contained in this publication. 


\section{Contents}

Executive summary

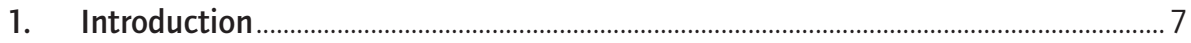

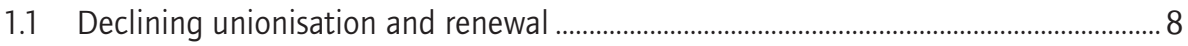

1.2 Workplace representation: at the core of union renewal ................................................ 10

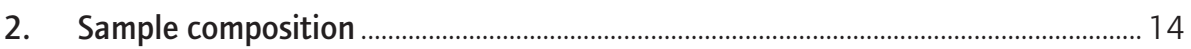

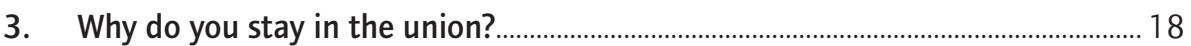

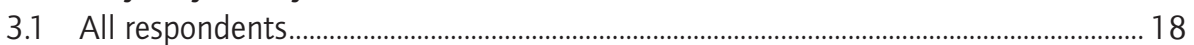

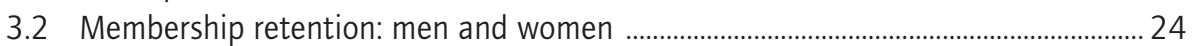

3.3 Membership retention: age groups ............................................................................. 28

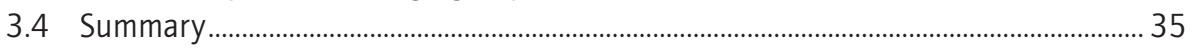

4. The views of union members on workplace representation ........................................... 37

4.1 The coverage and perceived quality of workplace representation............................... 37

4.2 The impact of representatives on perceptions of workplace industrial

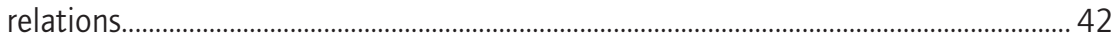

4.3 Comparing union performance with that of management............................................ 49

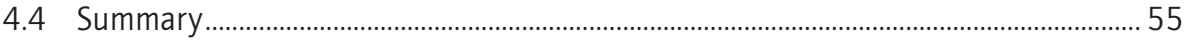

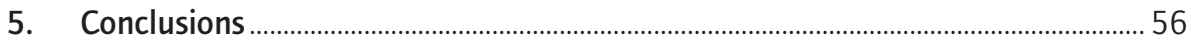

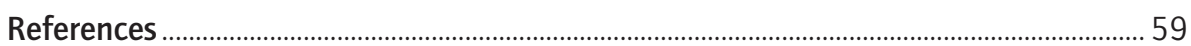





\section{Executive summary}

This Working Paper examines the reasons that underpin trade union membership retention in Europe and the impact of workplace representatives on the perceptions of the performance of trade unions among members. These themes are linked in so far as members view the performance of the union to be superior when there is a workplace representative present. In particular, the union is considered superior to management when a workplace representative is present and inferior in the absence of a workplace representative. The Working Paper explores these themes by means of a survey of fourteen trade union organisations based in twelve European countries.

Specifically, the Working Paper shows that:

1. 'Support if I have a problem at work' is the principal reason for retaining union membership among members in thirteen of the fourteen trade unions that participated in the research. With the one exception this finding applies irrespective of nationality, occupation or sector of union organisation.

2. In countries where a variant of the Ghent system operates (Denmark, Finland and Sweden) 'access to unemployment insurance' appears either at position one or two in the ranking of reasons for retaining union membership.

3. 'To improve my pay and conditions', 'I believe in trade unions and want to take part' and 'industrial and membership benefits' tend to appear towards the top of the ranking of the reasons for retaining union membership.

4. Women and young trade unionists tend to emphasise the importance of union support more than their male and older counterparts.

5. In the majority of unions that participated in the research between 25 per cent and 30 per cent of members do not have a representative present at their workplace: that is, the equivalent of either a shop steward or a works councillor.

6. Even if a representative is present at the workplace of members, a substantial number of members think that there are insufficient workplace representatives.

7. In only three unions were more than 50 per cent of the members content with workplace representation.

8. Members viewed the performance of the union more positively when a workplace representative was present. The presence of a workplace representative led members to view the performance of the union to be superior to that of management on a range of tasks, but members tended to view the performance of management to be superior to that of the union in the absence 
of workplace representatives. These findings apply to both single channel and dual systems of workplace representation.

The policy implications of these findings are threefold. First, irrespective of nationality, occupation, industry, sex and age trade unionists retain their membership because of a 'traditional' union agenda, based on fairness, equity and improvements in the terms and conditions of employment. The policy challenge is to deliver this agenda in a form appropriate to current labour market circumstances. Second, workplace representation is the bedrock on which any form of European trade union renewal should be founded. Third, these findings suggest that union renewal policies based on the deployment of workplace representatives to perform organising and recruitment activities in addition to their other representative duties may jeopardise how they are perceived by existing members, as many members already take the view that there are insufficient workplace representatives. 


\section{Introduction}

Throughout much of Europe unionisation rates have declined since the 1980s. While the extent of decline varies between nations, no trade union movement has implemented an effective strategy to restore the levels of the late-1970s leading some to question the relevance of trade unionism for the twenty-first century, the future role of trade unionism and the embeddedness of unions in globalised capitalism (Crouch 1986; Boeri et al. 2001; Hyman 2004). In essence, two inter-related literatures have addressed these aspects of unionism in comparative perspective: explanations of the decline in unionisation and analyses of trade union renewal or revitalisation strategies. This Working Paper adopts a third approach in identifying on a comparative basis why trade unionists retain membership during a period of membership decline and assesses the performance of unions at the workplace from the perspective of members. In adopting this approach the first objective of the Working Paper is to identify the reasons that underpin membership and assesses their implications for the renewal strategies implemented by trade unionists.

The workplace is the location of trade unionism for most trade unionists and the workplace representative is a key figure in generating collective identities. Where workplace representation remains in place the decentralisation of bargaining has increased the range of issues handled by, and hence the workload of, workplace representatives. Furthermore, new management practices include methods of direct communication with employees, which often bypass workplace representatives, may directly challenge their interpretation of events and may undermine the position of workplace representatives. To compound these challenges structural shifts in employment have contributed to a decline in the coverage of workplace representation. A second objective of this Working Paper is to chart the coverage of workplace representation and the views of union members towards workplace representation in fourteen union organisations based in twelve European countries.

The Introduction outlines the salient points of the literature on the decline of unionisation and trade union renewal or revitalisation. Thereafter the Working Paper comprises three sections. The first section outlines the composition of the survey sample. The second section identifies why unionists retain their membership. The third section assesses the impact of workplace representation on members' perceptions of union performance. Two arguments run through the Working Paper. First, 'traditional' reasons explain why trade un- 
ionists retain membership and central to these reasons is the performance of workplace representatives. Second, members with a representative present at the workplace rate the performance of the union to be superior compared to their counterparts with no representative present and to be superior to that of management: that is, the presence of workplace representation is a prerequisite to any form of union renewal and to the generation of union social capital.

\subsection{Declining unionisation and renewal}

Explanations of the decline in unionisation have traditionally been based on the impact of the business cycle (Bain and Elshiekh 1976; Schnabel 2003, 2013) and the changing composition of the labour force (Western 1997; Farber and Western 2001). Relying on similar econometric techniques, variants of these approaches highlight the impact on the decline in unionisation of changing relations between trade unions and political parties (Bean and Holden 1992; Thelen 1991), effects associated with the individual characteristics of workers (Blanchflower 2007; Schnabel and Wagner 2007) and the effect of the Ghent system (Western 1997). Advocates of these explanations argue that they explain a substantial proportion of the decline in unionisation since the 1970s. Three criticisms are levelled at these studies. First, regression analyses link unionisation to a set of national characteristics rather than explaining differences in the national rates of membership decline, hence ignoring the increasing divergence of national density rates (Ebbinghaus and Visser 1999). Second, these studies do not address variations in union strategy and associated questions, such as how is membership organised and what appeal, if at all, do unions have for members and potential members in current circumstances (D'Art and Turner 2008)? Third, unionism for most union members is not an issue of national economic indicators or politics, but is a function of workplace circumstances, a point downplayed in the application of national explanatory models (Hancké 1993).

Unlike comparative studies of the decline in unionisation, the renewal literature focuses on union strategy and the characteristics of potential members. The merits and limitations of strategic options such as servicing, partnership, organising and community unionism are debated (Heery 2002; Frege and Kelly 2004). Additionally, groups of workers that are under-represented within unions are identified and their specific requirements of, and their potential contribution to, trade unions are isolated. In particular, the requirements and potential contribution of young, temporary, migrant, women, part-time and, in some countries, white-collar workers are assessed as target groups (Cregan and Johnston 1990; Milkman 2000; Llorente Sánchez 2007). In contrast to the econometric modelling that is the mainstay of the literature on the decline in unionisation, examinations of union renewal are more reliant on case studies (Nissen 2002; Kloosterboer 2007; Turner and Cornfield 2007). The vast array of such evidence shows that the options available for renewal are not mutually exclusive analytically or strategically within unions (de Turberville 2007; Heery 2002), do not necessarily result in increases in 
membership or new forms of union governance appropriate to changed circumstances (Voss and Sherman 2000) and that there are differences between stated policy intentions and day-to-day practice in many unions (Heery and Simms 2008).

Integral to the literatures on the decline in unionisation and union renewal is a question that has been downplayed or omitted from both: namely, why do people retain their trade union membership in times of declining unionisation? Throughout Europe there is a perceived need for unions among unionists and non-unionists alike (D'Art and Turner 2008). Extant analyses of the specific question 'why do people retain their union membership?', however, tend to be national rather than comparative and, as the decision to remain a union member may be influenced by a range of social actors including managers, family members, work colleagues and union representatives, are often associated with examinations of how people initially joined the union. In this context Dutch workers cited improved terms and conditions of employment and to 'avoid personal problems in the work environment' (van de Vall 1970: 125-137; Klandermans 1986), British workers cited 'support if I have a problem at work' together with improved terms and conditions of employment (Waddington and Whitston 1997), while workers from the United States wanted more influence on workplace issues (Freeman and Rogers 1999: 40-43). Although the primary reason Danish workers joined unions was to gain access to the unemployment insurance funds operated by trade unions, they ranked 'to ensure that my interests are protected' as the second most important reason (Jørgensen et al., 1992). Similarly, young workers in Britain and the Netherlands mention that they were union members because other workers at their place of work were in the union (Cregan and Johnston 1990; Klandermans 1984). Membership retention is also associated with the quality of member services (Booth and Chatterji 1995), one of several observations that led many European trade unions to make available to members a range of financial services as an 'incentive' to membership retention.

The national focus of these studies coupled to differences in the wording used in the questionnaires or interviews precludes direct international comparisons. In the absence of such international comparisons the relative effect of different national institutions on membership decisions cannot be assessed. This paper remedies this shortfall in drawing on survey evidence from fourteen union organisations based in twelve countries. The paper shows that the reasons that underpin membership retention do not differ markedly between countries. Although there are differences in emphasis in the reasons for membership retention between unionists of different nationalities, between men and women and among unionists from different age groups, representation at the workplace is shown to be central to member retention throughout Europe 


\subsection{Workplace representation: at the core of union renewal}

The literature on trade union renewal or revitalisation and on the maintenance or regeneration of power places the activities of workplace representatives at the centre of union practices. It is thus necessary to highlight the influence workplace representation may bring to bear in these areas. The combination of institutions, state and employers' policies, and union structures and identities account for the variation in union strategic choices generally, and on union renewal strategies specifically (Frege and Kelly 2004:31-44). Most union renewal strategies, however, are underpinned by two assumptions. First, raising membership or density levels is important, but insufficient, for union renewal. Second, it is necessary to develop workplace representation in order to ensure that membership gains may be secured, at least, into the mediumterm, and that workplace organisation can become self-sustaining (Markowitz 2000; Simms et al. 2013:7-13). Workplace representation is thus both an object and a means of union renewal: an object in the sense that its development is a purpose of union renewal; a means in so far as workplace representatives are required to sustain renewed workplace organisation.

The implications of union renewal policies for workplace representatives in single channel and dual systems are wide-ranging. Within single channel systems the independence from management of shop steward organisation was derived, in part, from high levels of union density and strikes (Fairbrother 1984; Hyman 1996) and consolidated in some instances by managerial incompetence (Gallie and Rose 1996). The reassertion of managerial prerogative and the use of human resource management (HRM) techniques to bypass workplace representation subsequently exposed limitations in shop steward organisation (Purcell and Ahlstrand 1994; Martin 1985). These limitations were accentuated in the UK where declines in the level of union density and strike activity, coupled to the terms of the legislation enacted during the $1980 \mathrm{~s}$ and early 1990 s, resulted in a greater dependence on managerial acquiescence for the continued presence of shop stewards, particularly in the private sector (Charlwood and Forth 2009). Other single channel systems fared better, however, in so far as the legal underpinning to features of the industrial relations systems offered more support to shop steward organisation. The Ghent system, for example, facilitates the maintenance of high levels of union density, which, in turn, ensure employers engage with workplace representatives (Kjellberg 2006). ${ }^{1}$ Similarly, the Swedish Förtoendemannalagen (Workplace Union Representation Act) of 1974 specified the duties of workplace representation and allowed meetings in working time, thus consolidating workplace organisation. Even with such legal support, however, the confidence of Swedish union members in trade unions fell markedly between 1980 and 1990 (LO quoted in Kjellberg 1992:123-124).

1. In the Ghent system trade unions play a role in the administration of unemployment benefits, a procedure that encourages union membership (Kjellberg 2006). European countries in which versions of the Ghent system are in place include Belgium, Denmark, Finland and Sweden, the final three of which are included in the analysis that follows. 
The legal underpinning of works councils in dual systems has also had a marked impact on the character of union renewal policies. In Germany it is unlawful for employers to prevent the establishment of works councils, if requested by workforces, and the majority of works council seats are occupied by trade unionists. The capacity of employers to resist a union presence is thus severely limited. Furthermore, the efficacy of works councils is shown to be dependent upon resources provided by trade unions, notably in the form of research, training and legal expertise (Müller-Jentsch 1995). Although a more politically distant relationship between works councils and unions persists in the Netherlands (Visser 1995), trade unions and works councils in Austria and Germany have developed a relationship of mutual inter-dependence (Traxler 1998; Behrens 2009). In countries where the establishment of works councils depends on an initiative taken by employees, works councils have always been established in only a minority of eligible workplaces. In Germany, for example, the coverage of works councils is 10 per cent of eligible workplaces and between 38 per cent (East Germany) and 45 per cent (West Germany) of private sector employees. The proportion of works councillors in Germany that are not union members, however, has risen since the late-1960s (Ellguth and Kohaut 2010), a trend reproduced in the Netherlands (Visser 1995) and Austria (Traxler 1998), which, as unions are reliant on works councillors to organise new members, presents a challenge in the context of union renewal initiatives. In short, in both single channel and dual systems of representation union renewal initiatives place demands on workplace representatives and raise questions about the capacity of workplace representatives to effectively articulate the interests of trade union members while also deepening workplace organisation.

A second theme that resonates throughout recent literature on union responses to decline concerns the issue of power. One element of trade union power is institutional, which, to a degree, is a function of the extent and character of the legal underpinning of workplace representation (Hancké 1993). As mentioned above, the legal underpinning of workplace institutions is common to Austria, Germany, the Netherlands and Spain, where dual systems are in operation, but is not always present where single channel systems operate. Workplace representation is central to a second element of trade union power: organisational power. While a high level of union density is often viewed as prerequisite to the deployment of union power, issues of mobilisation and solidarity influence the 'social capital' of unionism whereby collectively organised networks of unionists provide mutual support both within and outside of the workplace and generate organisational power (Jarley 2005). Workplace representation is essential to the generation of social capital unionism. Earlier studies demonstrated how workplace representatives in single channel and dual systems were able to represent and mobilise members, to organise collective and solidaristic workplace organisation and, on the basis of their relations with members, to secure concessions from management (Batstone et al. 1977; Korpi 1978; Brandt et al. 1982).

The capacity of representatives to generate social capital among unionists may be questioned on four counts. First, shifts in the labour market effec- 
tively moved employment from areas of union strength to private sector services where workplace representation is more rudimentary (Dolvik and Waddington 2005) and the structural power of unionised employees tends to be more limited (Wright 2000). ${ }^{2}$ Associated with these shifts is the employment of more diverse workforces, which has generated a 'crisis of interest aggregation' (Müller-Jentsch 1988:177-178) as unions can no longer mobilise around a limited number of interests that are shared by most or all members, but are required to accommodate competing and often divergent interests. Furthermore, as older white male manual workers are over-represented as shop stewards and works councillors, the assumption that workplace representatives could represent an increasingly diverse workforce has come under increasing scrutiny (Briskin 1999; Healy et al. 2004).

Second, the decentralisation of bargaining has effectively increased the workload of representatives. While managers have tended to 'drive' decentralisation processes, the character of such processes varies markedly (Keune 2011). Although industrial bargaining formally remains in place throughout much of Western continental Europe, the range of issues handled at company and workplace levels has increased as managers have sought to take decisions as near as possible to their point of effect and companies have either left or failed to join employers' associations. Where bargaining takes place in the private sector in the UK it is almost exclusively at company level. Although policy initiatives intended to establish industrial bargaining were implemented in several Eastern European countries after 1990, employer resistance was sufficient to result in a relatively low coverage of bargaining conducted primarily at company level (Bohle and Greskovits 2012; Meardi 2012). Irrespective of whether decentralisation has been organised or disorganised (Lash and Urry 1987; Traxler 1995), the point remains that in both single channel and dual systems, decentralisation introduces additional challenges for workplace representatives and makes meeting members' expectations more difficult. In particular, decentralisation necessitates workplace representatives handling a wider range of issues, limits the access of workplace representatives to central management decision-makers and complicates articulation between workplace and union (Edwards and Podgursky 1986; Waddington 2001).

Third, as a means to generate social capital at the workplace and a mainstay of union democracy, workplace representation relies on the responsiveness of workplace representatives to the concerns of constituents and on the participation of members in decision-making. Changes in the labour market led many to question whether workplace representation was sufficiently sensitive to the concerns of a diverse membership. In addition, in single channel

2. Structural power is derived from the location of workers within the labour market. Workers with structural power may have acquired specific skills that are difficult to replace or may occupy key positions within production processes which allow them to impose significant costs on employers should industrial action occur (Silver 2003; Gumbrell-McCormick and Hyman 2013:30). Many workers in private sector services have relatively low levels of structural power as they have neither skills nor key positions within organisations from which they may impose costs on employers: for example, unskilled workers in hotels and catering. Among the workers in private sector services with structural power are those employed in transport. 
and dual systems member attendance at decision-making meetings is low or has declined and a vast number of elections to representative positions are not contested. Furthermore, even at the zenith of workplace organisation elements of bureaucratisation that contrasted with a democratic ideal were detected (Eldridge 1971; Hyman 1979). These elements 'distanced' workplace representatives from their constituents as the former assimilated a concern for the preservation of the institutions of workplace representation.

Fourth, a 'crisis of workers' loyalty to trade unions' was identified (MüllerJentsch 1988:177-178) as arising from the management policies designed to promote employee commitment to the goals of the enterprise and/or substitute management for trade unions as a source of advice (Bratton 2001: Heery et al. 2004). Direct communication between managers and employees that bypasses workplace representatives is an additional feature associated with HRM that challenges the role of the workforce representative (Boxall et al. 2007: Dundon et al. 2005). More effective managerial communications effectively challenge the capacity of local representatives to mobilise power resources, particularly when such communications promote workers questioning issues of solidarity and collective identity (Lévesque and Murray 2010). In order to encourage loyalty to the union workplace representatives are required to compete more intensely with management on communications in a manner that hitherto was not required. 


\section{Sample composition}

Questionnaire-based surveys distributed to the members of fourteen trade unions based in twelve countries were conducted between 2005 and 2010. In practice, the survey distribution within each union was conducted independently, as the negotiation of access and time management issues effectively precluded simultaneous distribution across all of the participating trade unions. The basic questionnaire design was sustained throughout the research with changes made only to accommodate institutional variation or differences in union policy. The questionnaire was designed in English and translated by industrial relations specialists into the language of the country within which it was distributed. In addition to extensive checks for meaning in the translations, the questionnaires were also piloted to ensure that potential respondents understood what was being asked of them and whether they had the information at their disposal to answer the questions in the survey.

Variation in the size of the distribution within each participating organisation was a function of cost, union membership size and the quality of union membership records. Within several of the participating organisations particular sections of the membership were selected as target groups for the survey. The target groups were selected by representatives of the participating unions and the author on the basis that members of the target groups were the subject of a union recruitment or organising initiative; were considered 'difficult' to organise and thus more information on them was deemed useful within the participating union; and/or, where possible, were employed in private sector services where levels of union density tend to be lower than elsewhere. As a consequence of this approach no claim is made here that the results are representative of the entire unions that participated in the survey. The survey was distributed only to working members: unemployed and retired members were excluded. Table 1 provides details of each distribution and a sketch of the participating organisations.

With two exceptions the questionnaires were distributed by post to union members at the address held by the union. The distribution comprised a sample, based on the membership records held by the participating unions. Completed questionnaires were returned either directly to the author or to the head office of the participating union where they were boxed while still in the return envelopes and then sent to the author. The first exception to this general procedure was the Spanish Comisiones Obreras (CC.OO) where the questionnaire was distributed electronically to members of four of the con- 


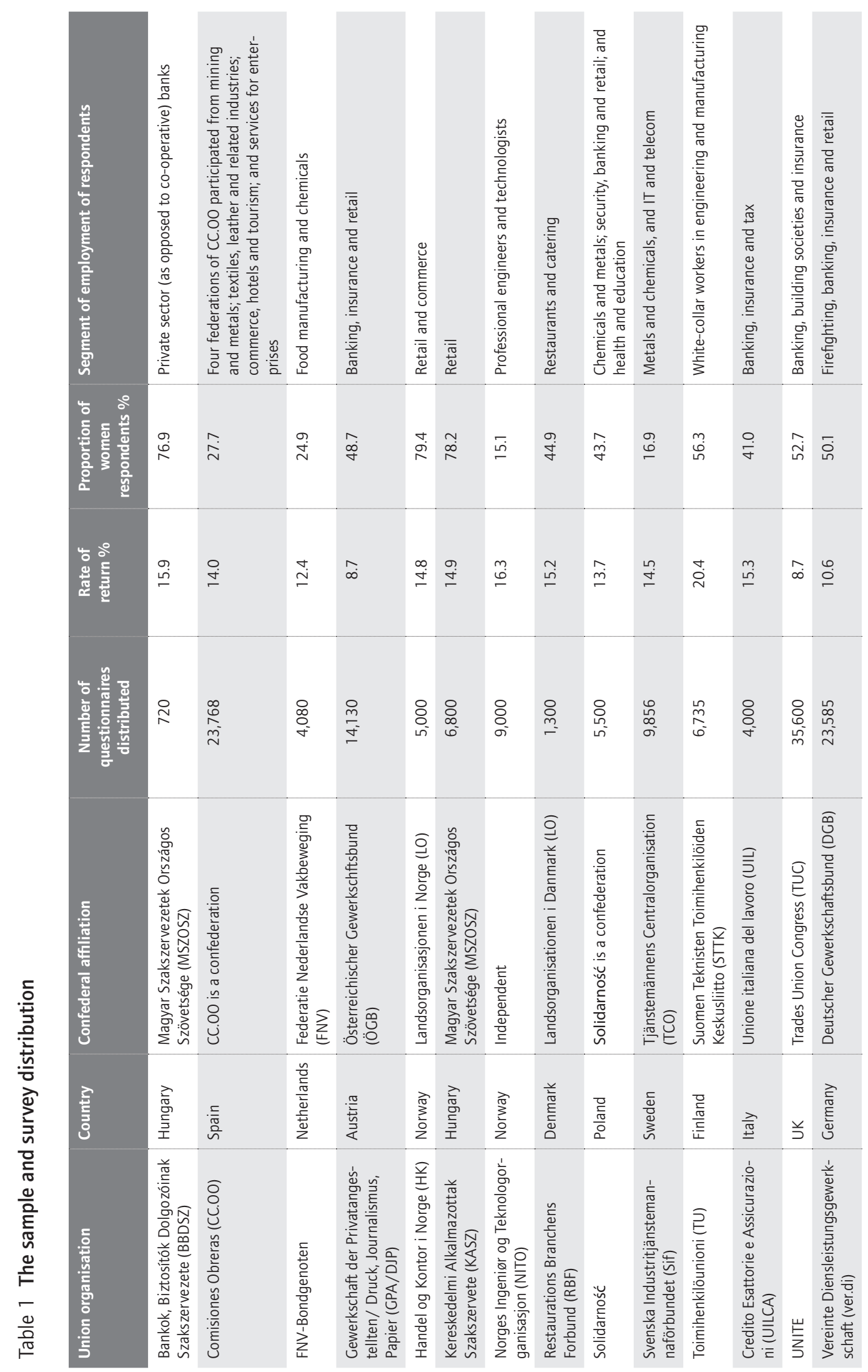


federal federations that had submitted their e-mail addresses. This procedure resulted in a skewing of the sample of returns towards younger members: median age of CC.OO respondents was between 37 and 38 years whereas that for all participating unions was between 43 and 44 years. The second exception involved the Hungarian Bankok, Biztosítók Dolgozóinak Szakszervezete (BBDSZ) and Kereskedelmi Alkalmazottak Szakszervete (KASZ) together with the Polish Solidarność. These organisations did not hold comprehensive membership records and thus there was neither the means to create a representative sample of the members nor to distribute the survey centrally. In consequence, the questionnaires were distributed by students to members at their place of work, collected by the students and then returned to the author via the head office of the union. A consequence of this approach is that the questionnaire returns tend to be drawn from large workplaces located in Hungarian and Polish cities and thus cannot be regarded as representative. To establish the priorities of members from Eastern Europe was considered sufficient justification to proceed on this basis.

Shop stewards in single channel systems and works councillors in dual systems are treated here as workplace representatives. Union workplace representatives established by some unions that operate in dual systems are thus excluded from the category 'workplace representative' employed here. ${ }^{3}$ The countries regarded as operating single channel systems from which participating unions are drawn include Denmark, Finland, Hungary, Italy, Poland, Norway, Sweden and the United Kingdom, whereas those operating a dual system include Austria, Germany, the Netherlands and Spain. In Hungary and Spain provisions allow for shop steward and works council representation. Hungary is treated as a single channel system in so far as the works councils established under the Labour Code of 1992 had only information and consultation rights, were often integrated into local union organisation, tended to be established only where union organisation was already present, and, in the main, left bargaining with management to the local union (Benyó et al. 2006; Tòth 1997). In contrast, Spain is treated as a dual system in that the Comite de Empressa (workers' committee) comprises representatives elected by the workforce in enterprises with 50 or more employees; has the right to negotiate company or workplace agreements, and to information and consultation; and the responsibility of ensuring compliance with external regulatory changes, such as on social security or employment legislation (Hamann and Martinez Lucio 2007).

Two further introductory remarks are noteworthy concerning trade union mergers and the participation of union confederations. Since participating in the survey three unions have merged with the result that they no longer exist

3. Of course, it is recognised that the rights, duties and status of shop stewards and works councillors differ within and between countries. As will become apparent, treating shop stewards and works councillors as a single category 'workplace representatives' is a means to facilitate the presentation of the argument developed here. Included among the workplace representatives excluded from the category 'workplace representative' are the Bedrijfscontactsman and Vertrauensleute established in the Netherlands and Germany. 
as independent organisations: the Danish Restaurations Branchens Forbund (RBF) merged in 2006 with Fagligt, Fælles, Forbund (3F); the Swedish Svenska Industritjänstemannaförbundet (Sif) merged with Handelstjänstemannaförbundet to form UNIONEN in January 2008; and the Finnish Toimihenkilöunioni (TU) merged to form Ammattiliitto PRO in January 2011. In each of these cases the confederal affiliation of the post-merger union is the same as that of the participating union. In addition, both CC.OO and Solidarność are union confederations. In the case of $C C . O O$ four federations participated in the survey, each of which organised in one of the segments of the economy listed in Table 1. Solidarność comprises about 8,300 company trade unions, 37 regional unions and 16 industrial unions that represent workers throughout the Polish economy. The survey was distributed among these three elements of Solidarność in the sectors mentioned in Table 1. 


\section{Why do you stay in the union?}

The data on 'why do you stay in the union?' are presented in three stages, which successively examine all respondents, men and women, and age groups. The sex and age group data are presented to explore arguments that women and young workers have different requirements of unions and thus remain in membership for different reasons. The Working Paper argues that there is a consistency across countries in the rank order of the reasons for membership retention, that there are differences in emphasis between men and women and between members of different ages for membership retention, and that representation and support at the workplace is central to membership retention.

\subsection{All respondents}

Respondents were asked to rank (one, two, three, etc.) their reasons for staying in the union from a closed list. Table 2 shows the results of this procedure for all members for each of the participating trade unions based on the issues ranked at positions one and two by each respondent. Respondents were also given the opportunity to indicate that 'another reason' was important to their membership retention. In only two unions, Credito Esattorie e Assicurazioni (UILCA) and KASZ, did more than 7 per cent of respondents indicate that 'another reason' was among the two principal reasons for staying in the union, suggesting that the closed list included the primary reasons for staying in the union for the vast majority of members.

Reference to Table 2 shows that, with a single exception, 'support if I have a problem at work' (hereafter, support) appears at position one in the ranking. In every union more than 55 per cent of members cited 'support' as one of the two principal reasons for staying in the union and in three unions more than 70 per cent of members adopted this position. The uniformity of these results suggests that if variation in industrial relations institutions is an influence on membership retention it is, at best, a second level influence. 'Support' appears at the head of the ranking, for example, irrespective of whether single channel or dual systems of workplace representation are in operation. It is acknowledged, however, that the provision of support to union members at their place of work varies in practice between single channel and dual systems, requiring different approaches by unions. 


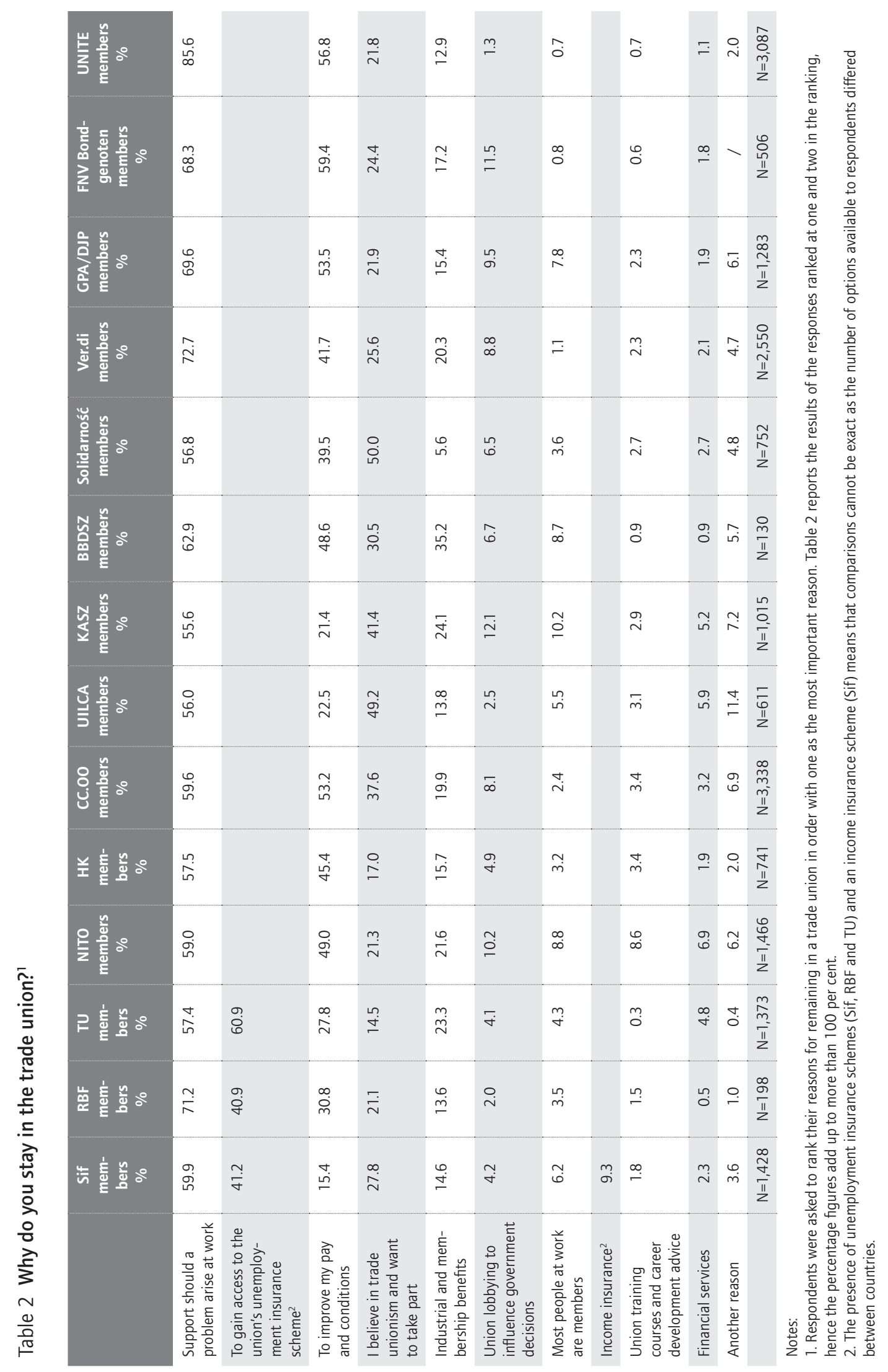


Four points arise from the results on 'support'. First, these results confirm the continued viability of 'mutual insurance' as a trade union method (Webb and Webb 1897:152-172). Second, these results are consistent with those on union leaving. UK research suggests that between 25 per cent and 35 per cent of union leavers do so because of inadequate workplace support offered by unions to members (Waddington 2006), whereas in the Netherlands and Spain inadequate support at the workplace accounts for 40 per cent and 35 per cent of leavers respectively (Visser 2002; Jódar et al. 2009:15). Third, the prominence afforded by members to 'support' indicates that union practices at the workplace and, in particular, the manner in which support is made available is key to membership retention. These results thus consolidate the view that well-developed union organisation in single channel systems or securing union workplace influence on works councils in dual systems underpins membership retention and promotes aggregate membership levels (Hancké 1993). Fourth, the quality of support available to members within both single channel and dual systems of representation is open to question in so far as only 57.7 per cent of members in single channel systems reported the presence of a shop steward at their place of work and 66.7 per cent of members in dual systems reported the presence of a work councillor at the workplace.

The exception to the pattern with 'support' at the head of the ranking is the Finnish TU where 'to gain access to the union's unemployment insurance scheme' (hereafter, access to unemployment insurance) heads the ranking. In Denmark and Sweden, the other two countries from which participating unions are drawn in which variants of the Ghent system operate, 'access to unemployment insurance' appears at position two in the ranking. The high position in the ranking of 'access to unemployment insurance' in the three Ghent system countries represented here confirms the impact of 'selective incentives' arising from variations in systems of unionisation and industrial relations (Olson 1965). 'Access to unemployment insurance' fails to appear consistently at the first position in the ranking in Ghent system countries, a result that contrasts with earlier research (Jørgensen et al. 1992). Two explanations underpin the variation. First, unemployment levels were lower in Denmark, Finland and Sweden when the current surveys were conducted compared to the levels of the early 1990s. As a consequence of lower levels of unemployment, employees are less likely to prioritise 'access to unemployment insurance' (LO 2005). Second, the relationship between 'access to unemployment insurance' and trade union membership has become looser and less transparent in recent years as a result of the establishment of unemployment insurance funds that are independent of trade unions and reductions in the levels of benefits available relative to wages (Kjellberg 2006; Lind 2009; Böckerman and Uusitalo 2006). While the research reported here does not allow assessment of the relative weight that might be assigned to these explanations, it is noteworthy that the 'income insurance' scheme offered exclusively to members by the Swedish Sif is designed to protect the level of benefits relative to wages. This scheme was cited by 9.3 per cent of Sif members as one of their two principal reasons for staying in the union. While this proportion is not high compared to that for 'support' and 'access to unemployment insurance' 
it reflects the influence of an attempt to modify the operation of the Ghent system in trade union terms on a basis that is exclusive to union members and compensates for government policies that have cut benefit provision (Kjellberg 2006). 'Income insurance', however, was a cost to Sif members that was additional to both membership contributions and the fee for the unemployment insurance fund.

There is more marked variation in the rank order of the reasons for membership retention between 'to improve my pay and conditions (hereafter pay), 'I believe in trade unions and want to take part' (hereafter belief), and 'industrial and membership benefits' (hereafter benefits). Members of four unions (Sif, UILCA, KASZ and Solidarność) rank 'belief' above 'pay', whereas members of three unions (TU, BBDSZ and [Norges Ingeniør og Teknologorganisasjon] NITO) assign a greater importance to 'benefits' than to 'belief' and members of one union (KASZ) rank 'benefits' higher than 'pay'.

The appearance of 'pay' at position two in the ranking for the majority of the participating unions is consistent with econometric explanations of changes in membership levels, which demonstrate that wages or real wages are influential on membership change (Bain and Elshiekh 1976; Schnabel 2013). Similarly to 'support', the high position in the ranking of 'pay' within most unions confirms the adherence of members to a longstanding trade union agenda based on fair and equal treatment at the workplace and improvements in terms and conditions of employment (Perlman 1928). Tests conducted to examine whether extant levels of pay among trade unionists influenced the prioritisation of 'pay' showed that the rank order of 'pay' did not change with variations in the level of pay among members. The relatively high position in the ranking of 'pay' confirms the centrality to membership retention of maintaining high rates of coverage of collective bargaining (Scheuer 2011). The contraction in the coverage of collective bargaining since about 1985 in Eastern Europe and more recently elsewhere, coupled to decentralisation (Schulten and Müller 2013), is thus likely to have had a negative effect on the capacity of union to retain members.

'Belief' appears in the ranking below 'pay' in ten of the fourteen participating unions and above 'benefits' in eleven of the participating unions with a range of scores between 14.5 per cent (TU) and 50.0 per cent (Solidarność). The highest scores recorded for 'belief' are in the unions from Central and Eastern Europe (KASZ, BBDSZ and Solidarność) and from Southern Europe (CC.OO and UILCA). While Hungary, Poland, Spain and Italy are characterised by competing union confederations in contrast to several of the other countries from which participating unions are drawn, there is no obvious argument to suggest that competing union confederations generate a greater ideological commitment to unionism per se as these results suggest. It is acknowledged, however, that making a choice of one from two or more union confederations may generate a greater ideological commitment to the chosen confederation. The results on 'belief' are generally positive for unions in so far as they suggest that an ideological commitment to unionism remains among a substantial section of the workforce, which is supplementary to the demand for union 
services. Furthermore, these results suggest that a proportion of members are still prepared to actively take part in union affairs.

The type of 'benefits' available to members of the participating unions varies markedly. While most of the unions in Western Europe offer a package of benefits that covers some or all of sickness, funeral, accident, injury and strike benefits, the Hungarian unions retain provisions for holiday accommodation in addition to some of the benefits offered by Western European trade unions. The value of the benefits available also varies. To illustrate, the sickness benefit available to TU members in Finland is of far greater value than that available to Solidarność members in Poland even after differences in Finnish and Polish living standards are taken into account. Given the extent of variation in both the range and the value of the available benefits it is remarkable that the position of 'benefits' is so consistent in the ranking with between 13.6 per cent and 20.2 per cent of the members of nine of the fourteen participating unions assigning 'benefits' as one of the two principal reasons for staying in membership. Two of the exceptions to this schema are BBDSZ and KASZ where 'benefits' receive relatively high scores, suggesting that the holiday accommodation provisions available since before 1990 remain important to membership retention. Both TU and NITO offer a range of benefits specific to professional engineers that may also explain why 'benefits' are valued relatively highly by members of the two unions. It remains to be seen if unions develop 'benefits' to compensate for the benefits withdrawn by states during the implementation of austerity programmes. Were unions to meet some of the shortfall arising from benefits withdrawn by states, the value of 'benefits' for membership retention may be enhanced (Johnston et al. 2012), as is illustrated by the 'income insurance' offered by Sif.

'Union lobbying to influence government decisions' (hereafter lobbying) tends to appear next in the ranking. Only in Solidarność does 'lobbying' appear higher than 'benefits', whereas in five unions (Sif, RBF, TU, UILCA and BBDSZ) 'most people at work are members' (hereafter most at work) appears higher in the ranking than 'lobbying'. Only in three unions, however, do more than 10 per cent of members regard 'lobbying' to be one of the two principal reasons for staying in the union (NITO, KASZ and [FNV-Bondgenoten] Bondgenoten). Furthermore, there is no apparent association between the importance assigned by members to 'lobbying' and the embeddedness of trade unions in national or state decision-making. NITO and KASZ, for example, are no more embedded in national or state decision-making than Handel og Kontor i Norge (HK) or BBDSZ. While members downplay 'lobbying' compared to workplace issues such as 'support', it should be acknowledged that unionists often lobby for workplace benefits such as improved health and safety legislation, indicating that the separation between 'lobbying' and the workplace is not necessarily clear-cut.

'Most at work' was included in the ranking as a means to assess whether establishing high membership density would encourage member cohesion in the form of high levels of membership retention. The low rank order and percentage scores assigned to 'most at work' suggest that density levels are not 
very influential on decisions to retain trade union membership. Clearly, at many of the workplaces where respondents were employed density levels would be low, bringing into question 'most at work' as an appropriate measure of the influence of union density on membership retention. Where density is high, such as among engineers in Sif and TU, there was no markedly greater effect of 'most at work' compared to unions that organise in private sector services where membership density tends to be lower, suggesting that the impact of density levels on membership retention remain low irrespective of the level of density achieved. This finding contrasts with earlier research showing that the probability of union membership increases with the perceived union density rate among co-workers (Visser 2002) and suggests that other factors may mediate the relationship between perceived density and union membership. ${ }^{4}$

Only in NITO do more than 3.5 per cent of members regard 'union training courses and career development advice' (hereafter training) as one of the two principal reasons that underpin membership retention. 'Training' is thus marginal to membership retention. The relatively high proportion of members in NITO that cite 'training' was primarily due to the professional training for engineers offered by the union. Even in these circumstances, however, 'training' was ranked in position seven of nine within NITO indicating that the professional training that was offered was not central to membership retention.

Packages of financial services have been introduced by many trade unions in Europe as a means to attract younger and, supposedly, more instrumental workers into membership and as a means of retaining extant members by offering discounted insurance and banking services. Similarly to 'benefits', the composition of the packages of financial services varies between participating unions. In particular, the range of financial services in the Eastern and Southern European trade unions tends to be narrower than that offered by trade unions based in Northern Europe. This variation, however, is not reflected in the results for 'financial services', which appear in the lower reaches of the ranking irrespective of the geographical location of the union. Fewer than 7 per cent of members regard 'financial services' as one of the two reasons for remaining in membership in every participating trade union. Furthermore, the longstanding and more traditional 'benefits' are more attractive than 'financial services' in all participating trade unions. The time, energy and cost of introducing 'financial services' seems misplaced in terms of membership retention, confirming earlier work on 'financial services' and union joining (Waddington and Whitston 1997).

4. The differences in the results between this study and that of Visser (2002) may also be influenced by the research methods employed. Visser (2002), for example, employed multivariate analyses. 


\subsection{Membership retention: men and women}

Although the influence of gender on decisions to unionise is contested, with some arguing no influence (Scheuer 2011) and others a significant effect (Blanchflower 2007), it is generally agreed that the proportion of women declines with seniority in unions resulting in adverse consequences for internal union equality and democracy (Hansen 2008; Ledwith and Colgan 2002) and that an equality agenda is underpinned by different requirements placed on unions by men and women (Briskin 1999; Milkman 2007) with women unionists prioritising social over economic factors and affective over instrumental relationships (Cunnison and Stageman 1993), tending to view unions as more ineffective than men (Sinclair 1995; Walters 2002), and finding the workplace and experiences of work to be gendered (Bradley 1999). This section examines whether these different priorities influence the reasons for membership retention. Table 3 shows the results for the fourteen unions disaggregated by sex.

Immediately apparent from Table 3 is that men and women rank the reasons for membership retention in the same general order. With the exception of TU, 'support' heads the ranking for men and women, followed in most cases by 'pay' in countries that do not operate the Ghent system. In Italy and Eastern Europe 'belief' appears above 'pay' in the ranking for men and women. It would thus appear that if different requirements are placed on unions by women and men these differences are found within the categories used in the ranking rather than in a re-ordering of the categories. Within the general order of the ranking, however, there are some marked differences in emphasis.

In twelve of the fourteen participating unions women placed greater emphasis on 'support' than their male counterparts. This result is consistent with earlier national studies (Klandermans 1984; Waddington and Whitston 1997) and findings that show women are more likely than men to cite the absence of 'support' as a reason for leaving unions (Waddington 2006; Jódar et al. 2009). Given that support is available at workplaces through either shop stewards in single channel systems or works councillors in dual systems it is noteworthy that among the survey respondents 60.3 per cent of men reported the presence of a shop steward at their place of work and 70.7 per cent the presence of a works councillor compared to 54.1 per cent and 61.4 per cent of women. In other words, the availability of support in the form of a representative at the workplace is more limited for women, suggesting that women are unlikely to receive the same support from workplace representatives as their male counterparts and that the coverage of representation is an element of an explanation of the differences in emphasis between men and women.

In ten of the fourteen participating unions women prioritise 'pay' to a greater extent than their male contemporaries, although the differences are less than five percentage points in six of these ten unions. Interpretation of these results is far from clear-cut. That women prioritise pay in the majority of unions, albeit marginally in some cases, at least brings into question the argument that women tend to downplay economic and emphasise social factors by compari- 
son with men, but may reflect an influence arising from the gender pay gap found in all the countries from which the participating unions were drawn. The category 'pay' as used in this research, however, also embraces other conditions of employment. The emphasis placed on the category by women could thus also result from a desire to pursue an equality agenda or other aspects of a collective bargaining agenda. Whatever the case, the emphasis placed on 'pay' by women confirms the policy requirement to increase the coverage of collective bargaining to embrace those areas of national economies where women form a majority of the workforce, but are excluded from collective bargaining, such as in segments of private sector services. Tests were conducted to establish whether existing levels of pay influenced the emphasis placed on 'pay' by men and women. No such influence was found with low paid men and women expressing a similar emphasis on 'pay' as their more highly paid counterparts.

Women downplay 'belief' compared to men in no fewer than twelve of the fourteen unions. Women expressed a stronger 'belief' than men in unionism only in HK and KASZ. Furthermore, in six unions (RBF, CC.OO, [Vereinte Dienstleistungsgewerkschaft] Ver.di, [Gewerkschaft der Privatangestellten / Druck, Journalismus, Papier] GPA/DJP, Bondgenoten and UNITE) the differences between the sexes was greater than ten percentage points. These results are also consistent with national studies (Klandermans 1984; Waddington and Whitston 1997). Interpretation of these results is again not straightforward. At one level the results suggest that women are not as ideologically committed to unionism as men even when they are already in membership. This explanation is certainly consistent with findings that demonstrate sex to be an influential variable on the decision to unionise, in so far as a lower ideological commitment to unionise may make recruitment more problematic (Blanchflower 2007). This explanation would be on firmer ground, however, if the absence of unions at workplaces where women are employed had not been shown to be the major influence on the effect of sex on unionisation rather than ideological differences (Walters 2002). Alternatively, and given that respondents to the survey were already unionised, the downplaying of 'belief' by women may result from the views of women members towards union organisation. For example, women may be pessimistic about the capacity of unions to implement internal changes favoured by women, the capacity of unions to exert influence on employers and the state and/or the gendered experience of unionism at the workplace. The limitations of representation at workplaces where women are employed, noted above, certainly supports an explanation along these lines.

Examination of the items positioned towards the bottom of the ranking reveals very few differences in the priorities of men and women. There are, for example, no consistent differences in the prioritisation of 'benefits'. Furthermore, differences between men and women in the percentage scores assigned to 'benefits' are relatively narrow. It is clear, however, that 'benefits' are more attractive than 'financial services' to both men and women in every participating union, again bringing into question the attraction of 'financial services' as a means of encouraging membership retention. Differences between men 


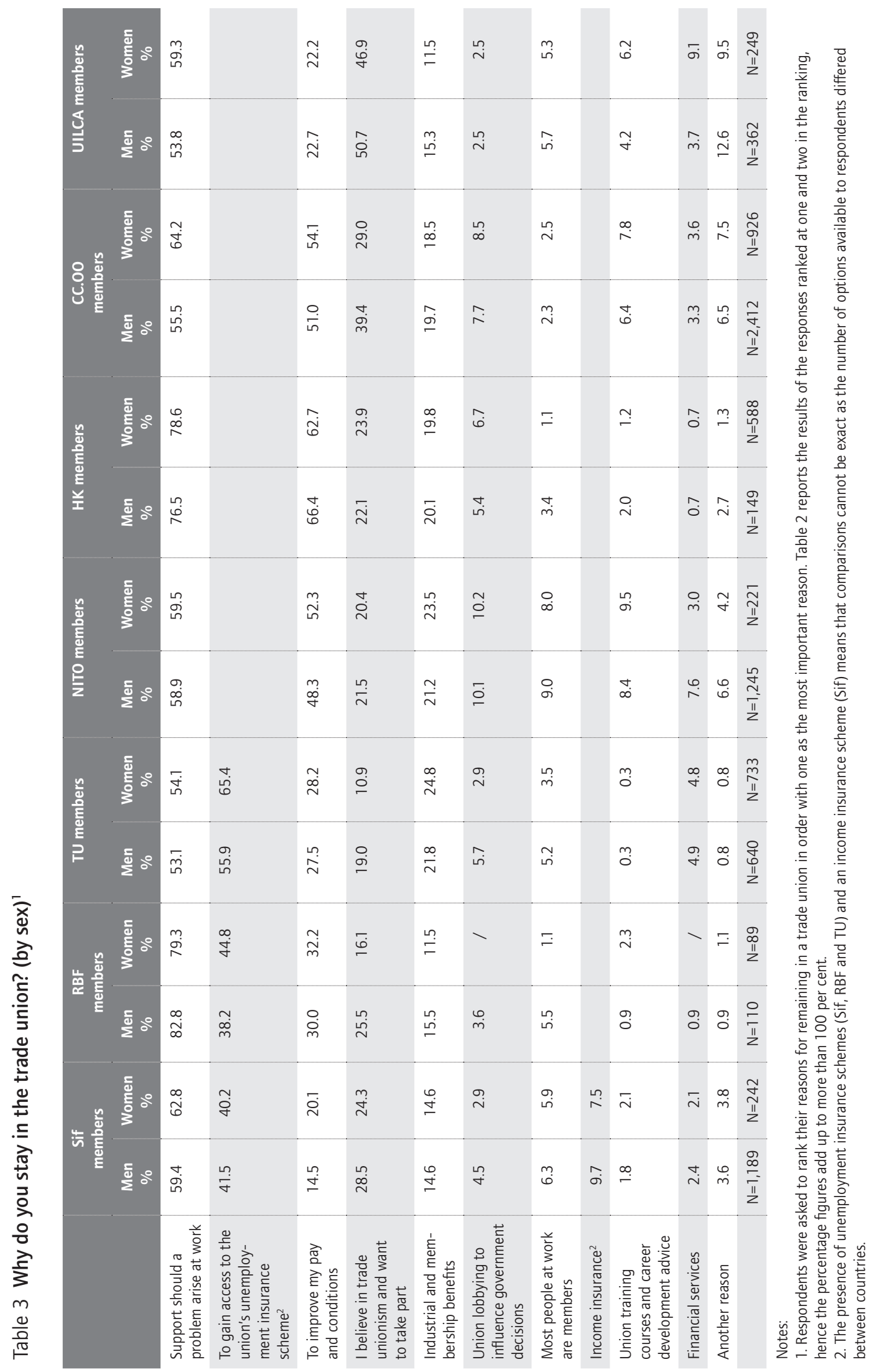




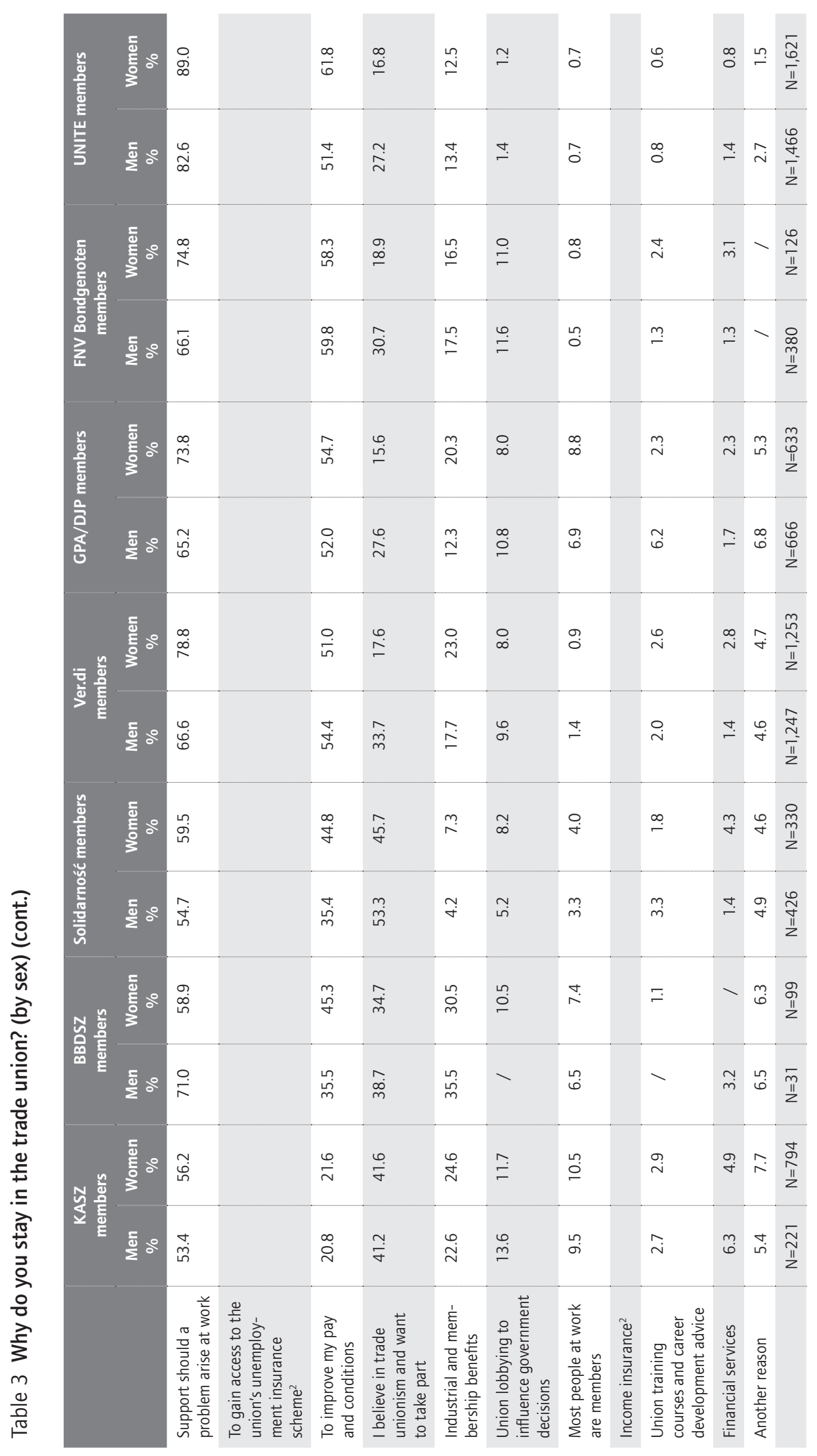


and women on 'lobbying', 'most people' and 'training' are negligible and show no consistent pattern, further supporting the idea that women have no particular conviction that unions can successfully lobby governments to implement an equalities agenda (Kirton 2005).

\subsection{Membership retention: age groups}

This section examines the reasons for membership retention by age. Evidence of low density among younger workers in Europe is widespread (Ebbinghaus et al. 2009) with the consequence that many union organising campaigns are directed specifically at young workers based on agendas deemed appropriate for young workers (Bailey et al. 2010; Pedersini 2010). There is a range of competing, but not mutually exclusive, explanatory frameworks for the lower unionisation rates among young workers. One explanatory framework detects a change in the propensity of young workers to unionise arising from the greater instrumentality and individualism exhibited by young people from recent generations compared to their earlier counterparts. Alternative explanatory frameworks emphasise both the propensity and the opportunity to unionise as underpinning lower unionisation rates among young workers. Both of these frameworks may also be influenced by the individualisation of the employment relationship in the form of decreases in the coverage of collective bargaining and restrictions placed in the collective legal protections available to workers (Freeman and Kleiner 1990; Peetz 2010). Such frameworks thus view the activities of employers, trade unions and the state as influencing the unionisation of young workers in addition to changes in attitude.

Within the terms of the framework established around changes in the propensity to unionise issues of ideology and instrumentality are examined here. The changed social, economic and political circumstances, marked, in particular, by the ascendency of the neo-liberal agenda, have resulted in changes in the attitudes, beliefs and ideology of young people (Cregan and Johnston 1990; Gomez et al. 2002). Associated with these changes are more instrumental attitudes and shifts in ideological perspectives that run counter to the collective orientation that underpins unionism (Kelloway and Newton 1996; Gomez et al. 2002). Furthermore, and accentuating these developments is the breakdown of many traditional points of social reference, which has limited the 'passing down' of union tradition through social and family networks (Giddens 1990). For this explanation to be supported by the data young workers would be expected to exhibit a more marked instrumentality and a lower ideological commitment to unionism than their older counterparts.

Within the terms of the explanatory frameworks that incorporate both the propensity and opportunity to unionise it is argued that young workers are concentrated in precarious employment at workplaces where unions are rarely present, hence the opportunity for young workers to unionise is reduced (Oliver 2010; Vandaele 2012). Workers of all ages in precarious employment desire to reduce job insecurity and their vulnerability to exploitation and intimidation (Levine et al. 2008). Should unions establish a presence at work- 
places where young workers in precarious jobs are employed an emphasis among the young members on support would be expected as young workers seek greater security and protection from exploitation and intimidation. An additional aspect of the opportunity to unionise argument related to young workers concerns the influence of extant levels of unionisation at the workplaces where they are employed on their joining or retaining union membership. Research shows that young workers are more influenced by extant unionisation rates than older workers (Klandermans 1984; Cregan and Johnston 1990). For the results of these national studies to be upheld on a comparative basis young members would be expected to cite 'most people' more frequently than their older counterparts.

For most participating unions four age groups are identified in Table 4: 25 and under, 26-40, 41-50 and 51 and above. For Sif, RBF, NITO and UILCA there were insufficient respondents from the 25 and under category, hence this category is excluded. The small number of respondents from Sif, NITO and UILCA aged 25 and under is, in part, a consequence of the length of the training required prior to taking up employment positions organised by these unions. Similarly, for BBDSZ each age group category comprised very few respondents with the consequence that the union is omitted from the analysis by age. The comparisons based on the age group '25 and under' thus focus on ten rather than fourteen trade unions.

The same general order of the reasons for membership retention for all and by sex is reproduced when the data are disaggregated by age in so far as 'support' tends to head the ranking followed by 'pay' or 'belief' in countries that do not operate the Ghent system. In TU 'access to unemployment benefit' remains at the head of the ranking for members until they are 50 years of age after which 'support' is emphasised. The most obvious variation from the general pattern is in Solidarność where workers aged 25 and under rank 'pay' above 'support', suggesting a greater instrumentality among younger workers. Two other inter-related features are noteworthy for Solidarność. First, there is an inverse relationship between age and the importance attached to 'pay'. Second, the gap measured in percentage points between 'support' and 'pay' increases with age for those aged 26 or more. In other words, 'support' becomes increasingly important relative to 'pay' with age in Solidarność.

Reviewing the variation by age across the participating unions reveals that young members tend to emphasise 'support' more than their older counterparts. Only in NITO, KASZ, Solidarność and UNITE, for example, did older age groups emphasise 'support' more than the youngest age group. The greater desire for 'support' from young members is consistent with the notion of reducing insecurity among members whose employment circumstances are precarious, although it is not an indication that unions are successful in this endeavour.

Differences between the age groups on 'pay' are relatively narrow. Furthermore, there is no consistent relationship between age and 'pay' across the participating unions. Indeed, there is no consistent relationship between age and 'pay' when smaller groups of unions are assessed, such as when disaggregated 


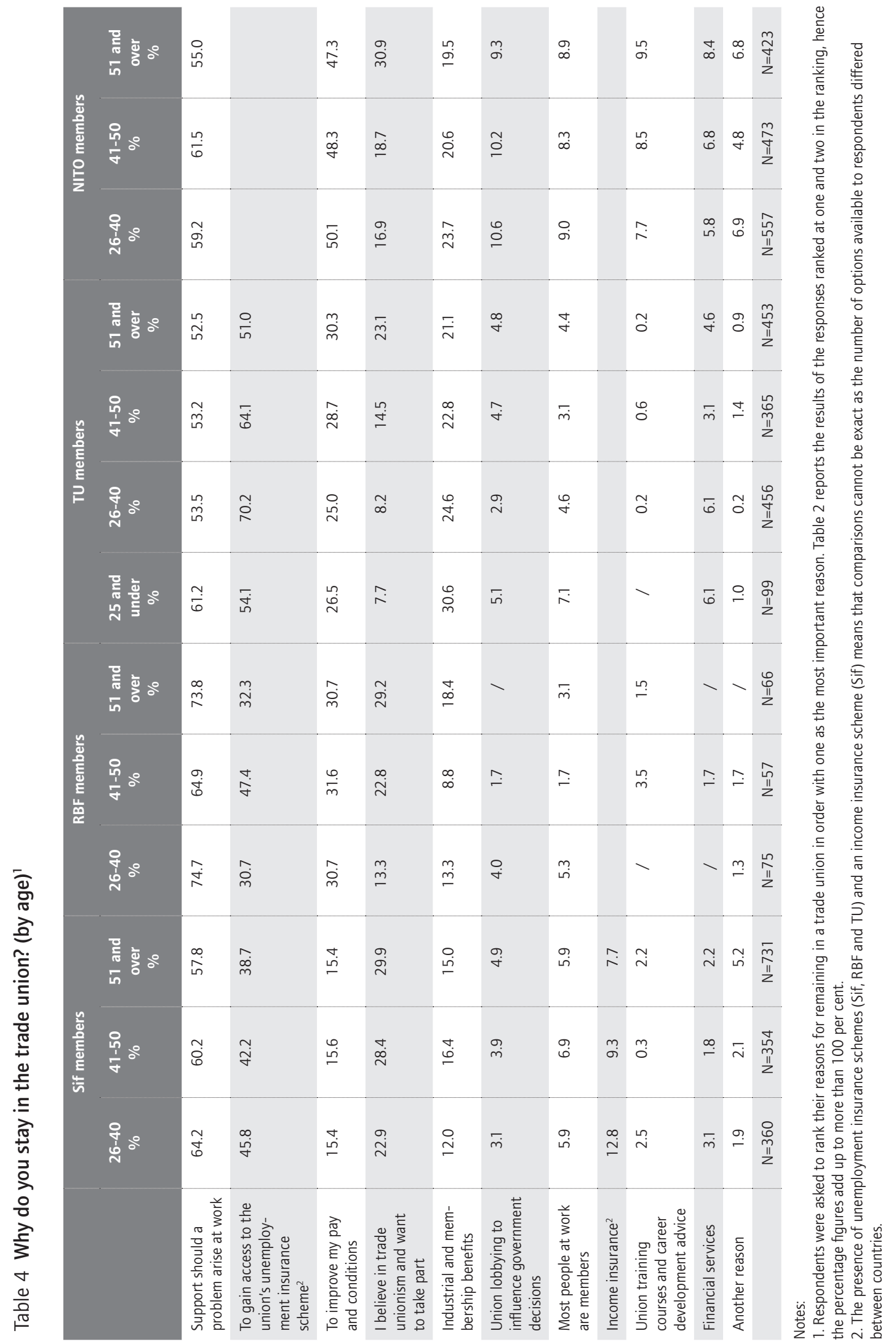




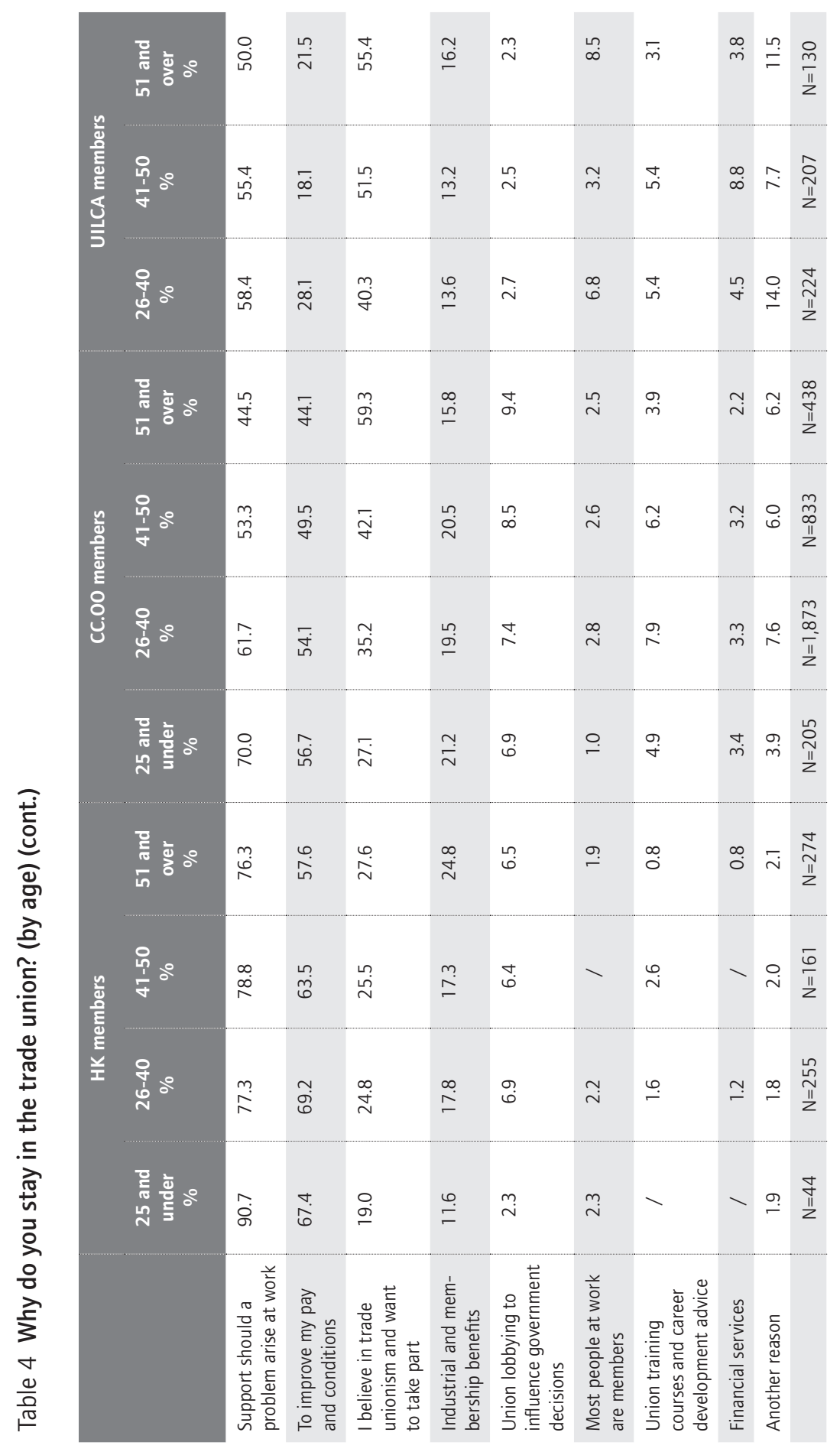




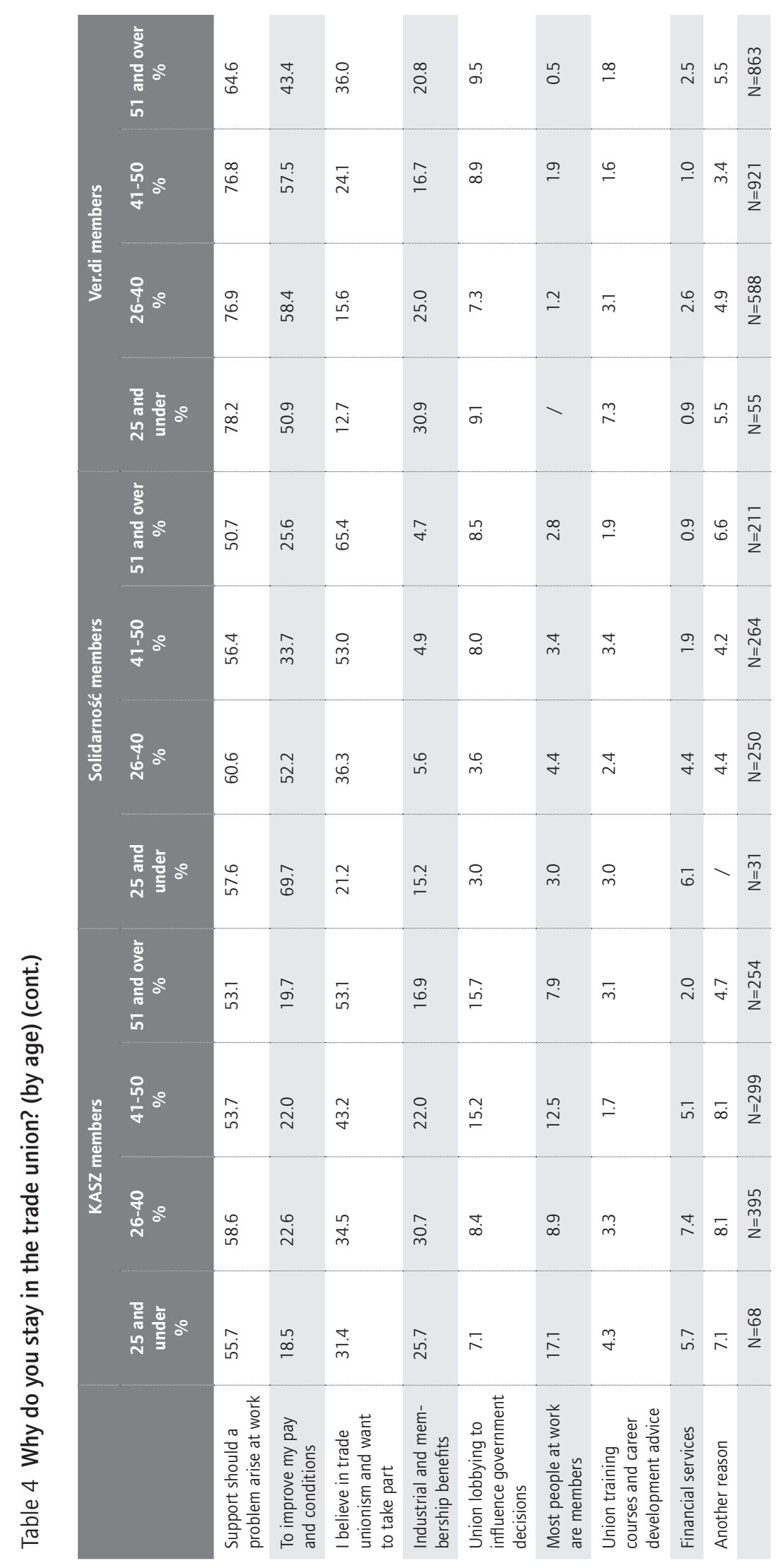




\begin{tabular}{|c|c|c|c|c|c|c|c|c|c|c|}
\hline & 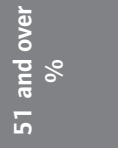 & 衣 & $\underset{\sim}{\sim}$ & $\stackrel{m}{\sim}$ & 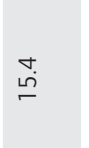 & $\stackrel{+}{\rightleftarrows}$ & $\stackrel{\infty}{\circ}$ & $\stackrel{\infty}{\circ}$ & $\stackrel{\circ}{i}$ & $\stackrel{\leftrightarrow}{m}$ \\
\hline 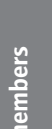 & $\begin{array}{l}\stackrel{\leftrightarrow}{\phi} \\
\frac{1}{\sigma} \circ\end{array}$ & ஷ̊ & $\stackrel{+}{\sigma}$ & $\underset{\sim}{\sim}$ & $\stackrel{Ð}{\circ}$ & $=$ & m. & ナ. & $\stackrel{m}{0}$ & $\stackrel{\circ}{\circ}$ \\
\hline $\bar{z}$ & 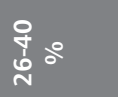 & $\begin{array}{c}\infty \\
\infty \\
\infty \\
\infty\end{array}$ & 芯 & $\stackrel{\leftrightarrow}{\stackrel{i}{~}}$ & $\stackrel{\circ}{\stackrel{m}{\sim}}$ & $\stackrel{\Xi}{\leftrightarrows}$ & $\stackrel{\circ}{\circ}$ & $\stackrel{\leftrightarrow}{\circ}$ & $\stackrel{m}{=}$ & $\stackrel{\circ}{i}$ \\
\hline & 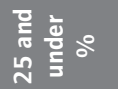 & $\begin{array}{l}n \\
\stackrel{\sim}{\infty} \\
\infty\end{array}$ & $\underset{\text { in }}{i}$ & $\stackrel{\stackrel{\rho}{x}}{\stackrel{2}{r}}$ & $\stackrel{\infty}{\check{C}}$ & $\stackrel{\bullet}{i}$ & $\stackrel{m}{r}$ & $\stackrel{m}{=}$ & - & $\stackrel{\circ}{i}$ \\
\hline & 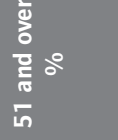 & 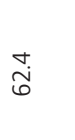 & $\frac{m}{\sigma}$ & $\stackrel{\stackrel{n}{\dot{m}}}{\mathrm{~m}}$ & $\stackrel{m}{=}$ & $\stackrel{\mathscr{g}}{\dot{I}}$ & - & $\stackrel{\stackrel{n}{\longrightarrow}}{\longrightarrow}$ & $\bar{i}$ & - \\
\hline 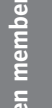 & 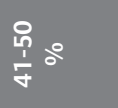 & $\stackrel{\circ}{\circ}$ & 苛 & 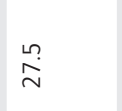 & $\stackrel{m}{\stackrel{n}{~}}$ & $\widehat{\infty}$ & - & $\stackrel{\sim}{\sim}$ & $\hat{o}$ & - \\
\hline 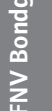 & 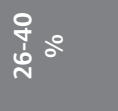 & $\underset{n}{n}$ & $\begin{array}{l}e \\
\stackrel{\text { in }}{n}\end{array}$ & $\stackrel{\sim}{\sim}$ & $\begin{array}{l}\stackrel{\sim}{\infty} \\
\infty\end{array}$ & $\stackrel{m}{\circ}$ & 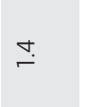 & $\hat{o}$ & $\stackrel{\nabla}{=}$ & - \\
\hline & 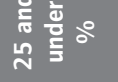 & $\begin{array}{l}\infty \\
\stackrel{\infty}{\infty} \\
\infty\end{array}$ & ơ & 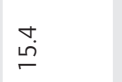 & $\underset{m}{+}$ & $\hat{\imath}$ & $\stackrel{\infty}{m}$ & $\stackrel{\infty}{m}$ & $\hat{r}$ & - \\
\hline & $\begin{array}{l}\frac{\mathrm{o}}{0} \\
\frac{0}{\mathrm{c}} \circ \circ \\
\frac{5}{5}\end{array}$ & 芦 & $\overline{\vec{F}}$ & 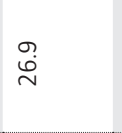 & $\stackrel{\sim}{\mathscr{V}}$ & $\stackrel{\circ}{\sigma}$ & $\bar{n}$ & $\stackrel{\sim}{\sim}$ & $\stackrel{\circ}{\mathrm{i}}$ & g) \\
\hline 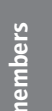 & $\frac{8}{\dot{p}} \frac{0}{4}$ & 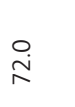 & 움 & $\stackrel{\stackrel{\sim}{i}}{ }$ & $\stackrel{\stackrel{\varphi}{r}}{\stackrel{m}{r}}$ & $\stackrel{m}{\circ}$ & $\stackrel{6}{\sim}$ & $\stackrel{\infty}{-}$ & $\stackrel{ \pm}{\leftarrow}$ & 它 \\
\hline 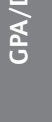 & 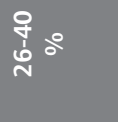 & $\stackrel{n ?}{\Gamma}$ & : & $\stackrel{\leftrightarrow}{\stackrel{\leftrightarrow}{\sim}}$ & $\tilde{\omega}$ & $\widehat{\infty}$ & $\stackrel{\sim}{\circ}$ & $\stackrel{\sim}{m}$ & $\stackrel{\mathscr{n}}{\mathrm{N}}$ & ถู \\
\hline & 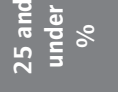 & $\begin{array}{l}n \\
\infty \\
\infty \\
\infty \\
\infty\end{array}$ & $\begin{array}{l}\stackrel{\infty}{n} \\
\end{array}$ & $\hat{\curvearrowright}$ & ì & $\stackrel{\infty}{m}$ & $\stackrel{\infty}{m}$ & $\stackrel{\infty}{m}$ & $\stackrel{\infty}{m}$ & $\stackrel{\infty}{m}$ \\
\hline & & 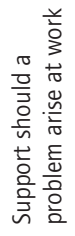 & 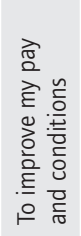 & 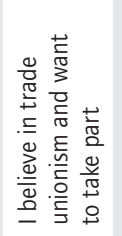 & 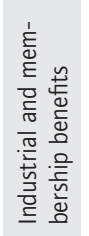 & 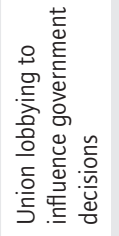 & 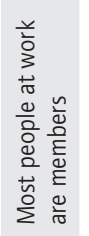 & 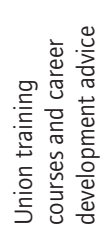 & 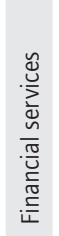 & 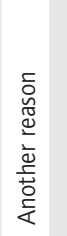 \\
\hline
\end{tabular}


by geographical location or the features of the industrial relations system in which they operate. The failure of young members to emphasise 'pay' does not suggest more instrumental attitudes among those young workers that join unions compared to their older counterparts. The findings on 'pay' thus do not support the argument that young workers are more instrumental than older workers. Furthermore, there is no consistent relationship between age and 'access to unemployment insurance', again suggesting that instrumentality and age are not directly related. Of course, it may be that the young workers that join unions have different attitudes on instrumentality than nonunionists, but assessment of this argument is beyond the scope of this paper.

There is a positive relationship between age and 'belief' in every participating union. Given that 'belief' was specified in the questionnaires in terms of a belief in and a desire to take part in trade unions, the positive relationship indicates that there is less ideological conviction among young members than among their older counterparts. This suggests that the ideological changes associated with the ascendency of the neo-liberal agenda are not necessarily restricted solely to the choice between unionisation or non-unionism, but may also impinge on the ideological convictions of young unionists. The positive relationship between age and 'belief' also suggests a greater instrumentality among young members in so far as they are prepared to join a union, but are more reluctant to take part than their older counterparts: that is, they wish to benefit from union membership without necessarily engaging directly in union activities. Both of these points raise significant policy challenges for trade unions as they suggest a different ideological disposition among young workers compared to older workers and a reduced likelihood of active participation in union affairs, a 'willingness to pay' without an accompanying 'willingness to act' (Offe and Wiesenthal 1979). At the very least, these results highlight a role for union education in the 'socialisation' of young members. What is unclear from these results, however, is whether members come to believe in trade unionism as they age and are more exposed to unionists and unionism at the workplace. While the positive relationship between age and 'belief' certainly suggests that such exposure with age may influence attitudes, only by tracing the ideological convictions of a cohort of unionists over time would it be possible to confirm this argument.

Relative to 'support', 'pay', 'belief' and 'benefits' the proportion of respondents that cite 'most people' is small across all age groups. Furthermore, there is no consistent evidence of young members being more likely to cite 'most people' than older unionists. In seven of the thirteen unions detailed in Table 4 the youngest age group is the most likely to cite 'most people', but only in KASZ did more than 15 per cent of the 25 and under age group cite 'most people'. With the exception of Sif, young workers in the Nordic trade unions were more likely than older workers to mention 'most people'. There are, however, no other geographical concentrations of unions or groups of unions organised by the characteristics of industrial relations systems within which young workers cite 'most people' at a greater frequency than older workers. These data thus suggest that the influence of extant unionisation rates is not more pronounced among young members than on their older counterparts. 
'Financial services' were not more attractive to young members than to older members. Although in six of the thirteen unions (Sif, TU, CC.OO, Solidarność, GPA/DJP, Bondgenoten) the youngest age category was the group most likely to cite 'financial services' as one of the two principal reasons for membership retention, the 7.7 per cent of members aged 25 and under in Bondgenoten was the largest category to cite 'financial services'. In other words, young members are not consistently more attracted by 'financial services', which remain marginal to membership retention across all age groups in the participating unions. These results further bring into question an increased instrumentality among young members. Furthermore, the youngest age group in every union for which data are presented in Table 4 ranked 'benefits', many of which had their origins in the early twentieth century if not before, higher than 'financial services', suggesting that the development of these more traditional union services to meet the circumstances of today would be a more advantageous approach for trade unions in Europe than offering an ever-wider range of financial services.

\subsection{Summary}

In identifying the reasons that underpin membership retention within European trade unions this section of the Working Paper has highlighted four points. First, 'support' followed by 'pay' underpins membership retention in most countries. The importance attached to these issues of longstanding centrality to the raison d'être of trade unionism suggest that a traditional desire to be treated fairly and to be rewarded appropriately remain apposite to any current trade union membership strategy. The importance attached to these issues also reflects the continued salience of collective reasons to membership retention. Recent initiatives intended to respond to the supposed increased instrumentality and individualism of potential members in the form of 'financial services' are marginal to membership retention. Traditional 'benefits' remain more attractive than 'financial services', suggesting that at issue may not be individualism or instrumentality, but the type of service that is available.

Second, the delivery of 'support' at the workplace requires robust workplace organisation. Although the character of such workplace organisation will differ between single channel and dual systems of representation, the point remains that the coverage of workplace organisation is declining in the majority of the countries assessed in this study. Similarly, the delivery of improvements in 'pay' constitutes a further challenge for trade unionists in the light of the contraction in the coverage of collective bargaining and the decentralisation of collective bargaining that is characteristic of the twelve countries within which the participating unions operate (Aidt and Tzannatos 2008; Traxler et al. 2001), effects that have been exacerbated by the impact of the post-2007 crisis (Schülten and Müller 2013). In short, activity at the workplace is key to the delivery of 'support' and, with the decentralisation of collective bargaining, is becoming more central to securing improvements in 'pay', yet more than 40 per cent of members in single channel systems and more than 30 per 
cent of members in dual systems report no shop steward or works councillor to be present at their workplace.

Third, men and women rank the reasons for membership retention in the same general order. Differences between the sexes in the reasons for membership retention are within the categories employed here rather than the order in which they are ranked. Women, however, emphasise 'support' more than their male counterparts. The increased desire for support among women may result from there being fewer representatives at workplaces where women are employed. Similarly, women downplay 'belief' compared to men. Whether the downplaying of 'belief' results from different ideological outlooks between men and women, a greater pessimism among women regarding the capacity of unions to exert influence or the gendered experience of unionism at the workplace remains an open question vis-à-vis the data presented here.

Fourth, 'pay, 'benefits' and 'financial services' were no more likely to be cited by younger workers than by their older counterparts, suggesting that the greater instrumentality noted by some among young workers (Gomez et al. 2002) does not extend to young unionists. Young trade unionists emphasised 'support' more than older unionists, again confirming the centrality of workplace representation to trade unionism. Age and 'belief' are directly related in each of the participating unions, raising questions as to whether young unionists exhibit different ideological perspectives and are less willing to take part in union activities compared to older unionists. The impact of union education and 'socialisation' remains an open question, which can best be directly addressed through the examination of cohort data. 


\section{The views of union members on workplace representation}

The views of trade union members on workplace representation are examined in three stages. The first stage establishes the coverage of workplace representatives and the extent to which union members regard workplace representation as satisfactory where representatives are present. The second stage explores unionists' views of union-management relations and the quality of the performance of the union at the workplace. The third stage compares the performance of workplace representation with that of management on a range of communication and related issues.

The analysis features comparisons between the views of unionists at workplaces where a representative is present and the views of unionists employed at workplaces with no representative. For the unions in the sample based in single channel systems 57.7 per cent of unionists reported the presence of a shop steward whereas 66.7 per cent of unionists in dual systems reported the presence of a works councillor. These figures do not indicate that the legal underpinning of works councils in dual systems necessarily results in a higher coverage, as there is marked sectoral variation in the composition of the two samples. Three limitations are acknowledged regarding the approach used here for shop stewards and works councillors. First, the categories shop steward and works councillor are analysed as undifferentiated: that is, no account is taken of the sex, age or other demographic characteristics of the representative and how these may influence relationships with unionists and the articulation of different interests. Second, distinctions are not drawn between unionised and non-unionised works councillors, although it is acknowledged that unionised works councillors are more likely to promote the union than their non-unionised counterparts. Union members with a works councillor present at their workplace reported that 77.8 per cent of works councillors were unionised. Third, no attempt is made here to incorporate an analysis of the impact of workplace union representatives in dual systems, which may supplement that of works councillors.

\subsection{The coverage and perceived quality of workplace representation}

The initial point of departure establishes the coverage of workplace representation and the extent of satisfaction among unionists with the performance of workplace representatives. Table 5 presents the results. The results from 


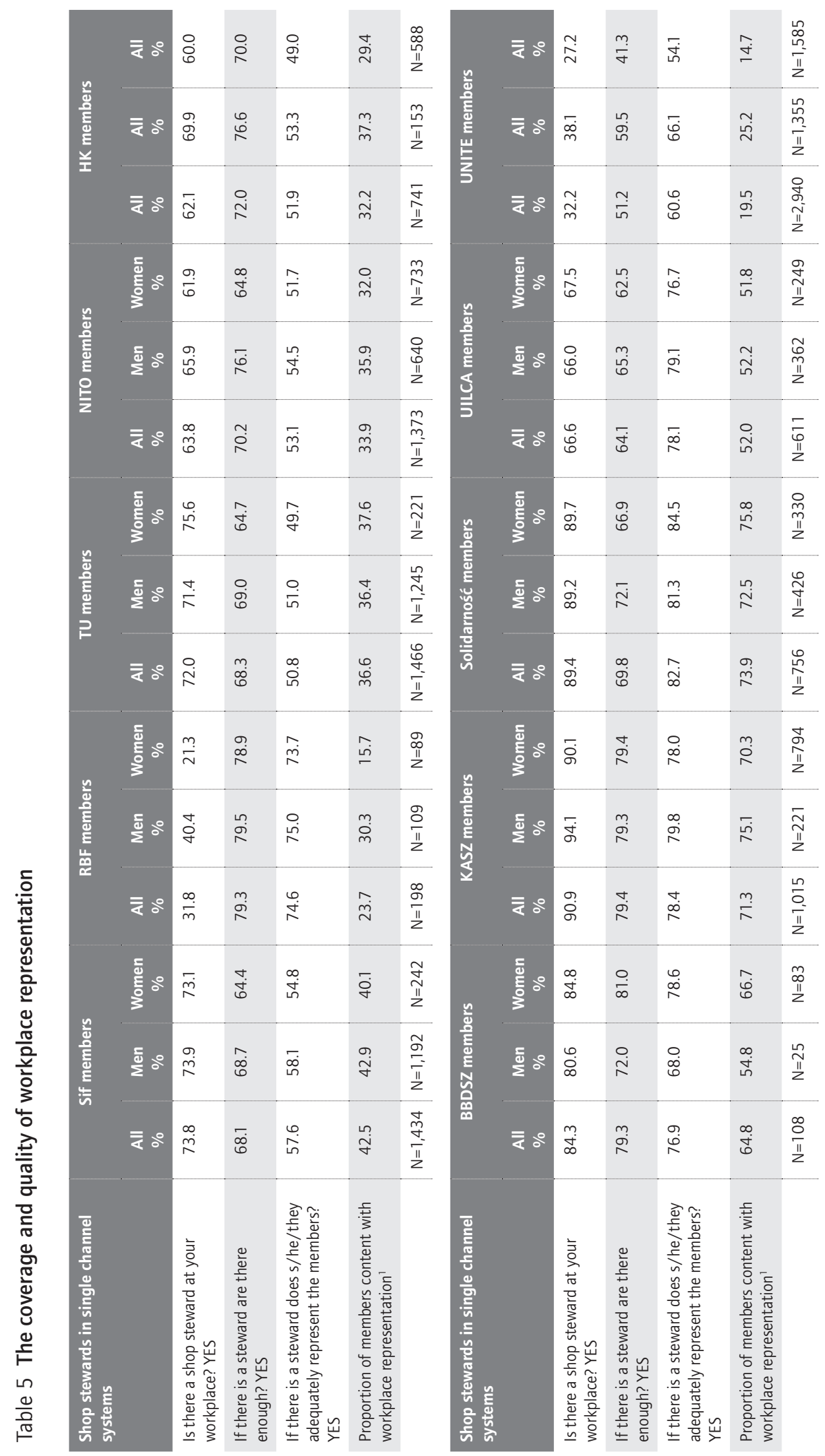




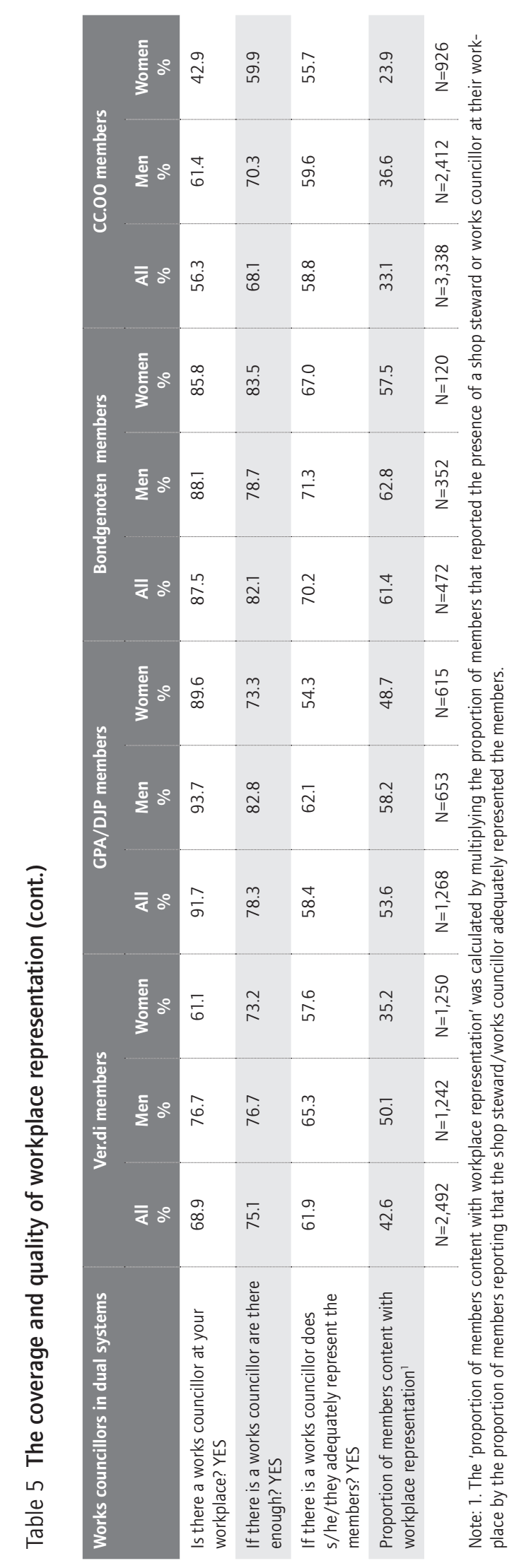


Hungary and Poland should be treated with some caution, as the method of survey distribution is likely to result in a disproportionately large proportion of questionnaires being distributed at sites where workplace representatives are present.

Four points are immediately apparent from Table 5 regarding the coverage of workplace representation. First, the coverage of workplace representatives for most unions is in the range 56.3 per cent (CC.OO) to 91.7 per cent (GPA/DJP). For the majority of unions between 25 per cent and 30 per cent of members do not have a representative present at their workplace. Given that every union that participated in the research had adopted a policy of trying to ensure that all members had access to a representative at their place of work, it is clear that considerable work is required before this target is met. Second, the lowest coverage of workplace representation is among the hotel and restaurant workers of RBF (31.8 per cent) and the bank and insurance workers of UNITE (32.2 per cent) where less than a third of unionists share a workplace with a shop steward, confirming that sector and workplace size are influential factors on coverage rates. Further evidence supporting this argument is available in Ver.di where the coverage rate of works councillors for fire fighters in the public sector is 90.1 per cent compared to 65.2 per cent for Ver.di members in retail, banking and insurance. Third, it is only in TU, UILCA, BBDSZ and Solidarność that a greater proportion of women than men report the presence of a representative at their workplace. In all of the unions operating in dual systems and most of the unions operating in single channel systems men are more likely to report the presence of a representative at their workplace. Campaigns to ensure the presence of a representative at every workplace where members are organised are thus less developed in feminised segments of the labour force. Fourth, the argument that workplace representation in dual systems has been more resilient than shop steward organisation in single channel systems (Jacobi et al. 1992) receives only partial support from Table 5. The direct comparison of UNITE and Ver.di members in banking and insurance illustrates the relative resilience of workplace representation in dual systems in so far as twice as many Ver.di members (68.9 per cent) than UNITE members (32.2 per cent) report the presence of workplace representatives. Comparison with UILCA, where 66.6 per cent of members have a shop steward at their workplace and membership is also organised in banking and insurance, shows that workplace representation in single channel systems can be resilient. The distinction drawn between single channel and dual systems is thus insufficient to explain differences in the coverage of workplace representation.

If a workplace representative is present, respondents were asked to indicate whether there are enough workplace representatives. The range of responses citing that there were sufficient representatives varied from 51.2 per cent in UNITE to 82.1 per cent in Bondgenoten. Even if a workplace representative is present substantial numbers of members thus think that there is an inadequate number of workplace representatives present. There appears to be no straightforward relation between the presence of a workplace representative and members' views as to whether there are enough workplace representa- 
tives. Although the coverage of workplace representatives in RBF is only 31.8 per cent, for example, almost 80 per cent of members with a representative at their workplace thought that there were sufficient numbers, putting RBF towards the top of the range. In contrast, UNITE is at the bottom of the range on both the coverage and the number of representatives.

A means to ensure the presence of a sufficient number of workplace representatives is most pressing for women unionists. In only three of the participating unions (BBDSZ, KASZ and Bondgenoten) did a greater proportion of women than men think that there were enough representatives. Women were thus less likely to have a workplace representative present at their workplace and were less likely to think that there were enough representatives if one was already present.

Given the number of members who work alongside workplace representatives, but think that there is an insufficient number of representatives present at the workplace, it is not surprising that a substantial minority of members take the view that extant workplace representatives do not adequately represent union members. Between 50.8 per cent (TU) and 82.7 per cent (Solidarność) of members with a representative at their workplace thought that the representatives adequately represented members. From the perspective of union members there are thus substantial numbers of workplace representatives who are not viewed as adequately undertaking representative duties. A range of factors may explain this result, included among which are the unwillingness of members to take on representative responsibilities resulting in low numbers of workplace representatives, the availability and/or willingness of representatives to undertake training, a reluctance among managers to sanction sufficient facility time, and high expectations among members about what can be achieved in current economic and political circumstances.

In twelve of the fourteen participating unions (exceptions BBDSZ and Solidarność) men are more likely than women to report that representatives adequately represent members. As mentioned above, women in the majority of unions were also less likely than men to have a representative present at the workplace and were less likely to think that there were enough representatives if one was already present. Women emphasise support from unions more than their male counterparts as a reason for both joining and retaining union membership (Klandermans 1984; Waddington and Whitston 1997). The dissatisfaction among women compared to men with extant representation, even if a representative is present at the workplace, introduces an additional feature to the issue of workplace support from unions and raises questions about the nature of this support, which are discussed in more detail below.

The final row of data in Table 5 reports the proportion of members that are content with workplace representation defined here as the presence of a representative at the workplace combined with members thinking that they are adequately represented. Putting aside the results from BBDSZ, KASZ and Solidarność for the reasons mentioned above concerning the method of the survey distribution, in only three unions (UILCA, GPA/DJP and 
Bondgenoten) were more than half the members content with workplace representation. In five unions operating in single channel systems (RBF, TU, NITO, HK and UNITE) and the four federations of CC.OO that operate in a dual system fewer than 40 per cent of members are satisfied with workplace representation. In only three unions (TU, BBDSZ and Solidarność) is a greater proportion of women than men content with workplace representation. The extent of dissatisfaction among trade unionists with workplace representation raises questions about the issues on which satisfaction or dissatisfaction is expressed. Stages two and three of the analysis address these questions.

\subsection{The impact of representatives on perceptions of workplace industrial relations}

Stage one showed that large numbers of trade unionists are employed at sites where there are no workplace representatives present and that many members with a representative at their place of work think that the quality of representation could be improved. Stage two compares the views of unionists with and without a representative at their workplace on issues concerned with union-management relations and on the performance of the union on a number of basic tasks.

Five statements on union-management relations are identified in the upper panel of Table 6. Overall, members are more positive in assessing these statements when there is a representative present at their workplace: in only sixteen of the seventy cases were members with a representative less positive than their counterparts with no representative present. ${ }^{5}$ Furthermore these sixteen cases were distributed across the range of industrial relations systems represented here. Two such cases were in CC.OO based in a dual system, seven cases occurred in Nordic unions, four in the unions based in Eastern Europe, two in UILCA and one in UNITE. The greater political 'distance' between Dutch works councils and trade unions compared to that in Austria and Germany is thus not reflected in the perceptions of the members of Bondgenoten.

In every union, however, members with a representative present at the workplace were more likely to view the union as 'well organised' than members with no representative and in ten of the fourteen unions the score with a representative present was positive whereas that with no representative present was negative. While there may be an impact linked to the non-unionisation of some works councillors in dual systems, it is insufficient to change the direction of the relationship between the presence of a works councillor and the perceptions of members of union organisation. The differences in the percentage scores on 'well organised' between members with and without

5. Fourteen organisations participated in the research and for each union there are five statements of union-management relations. In all there are thus seventy cases. 


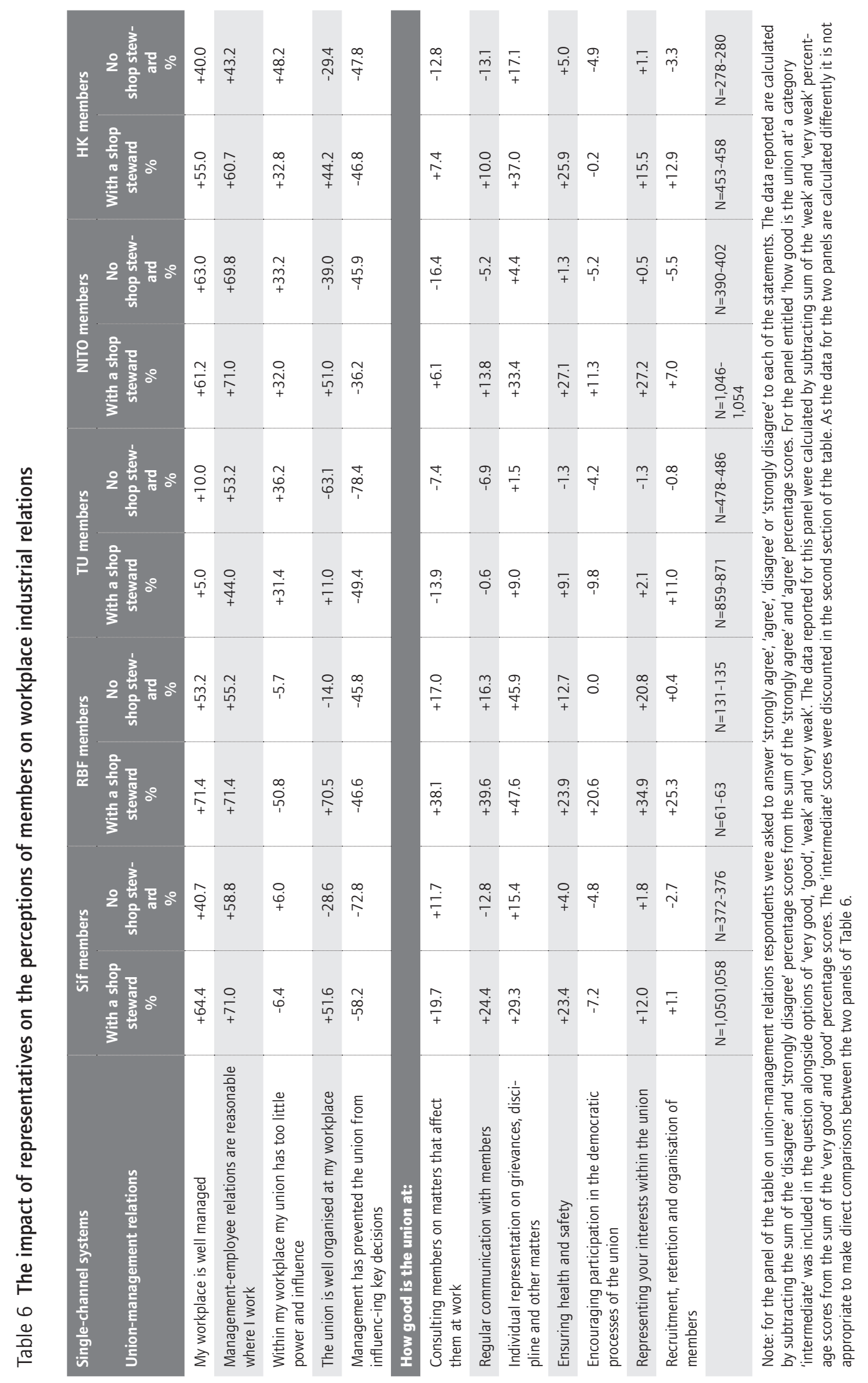




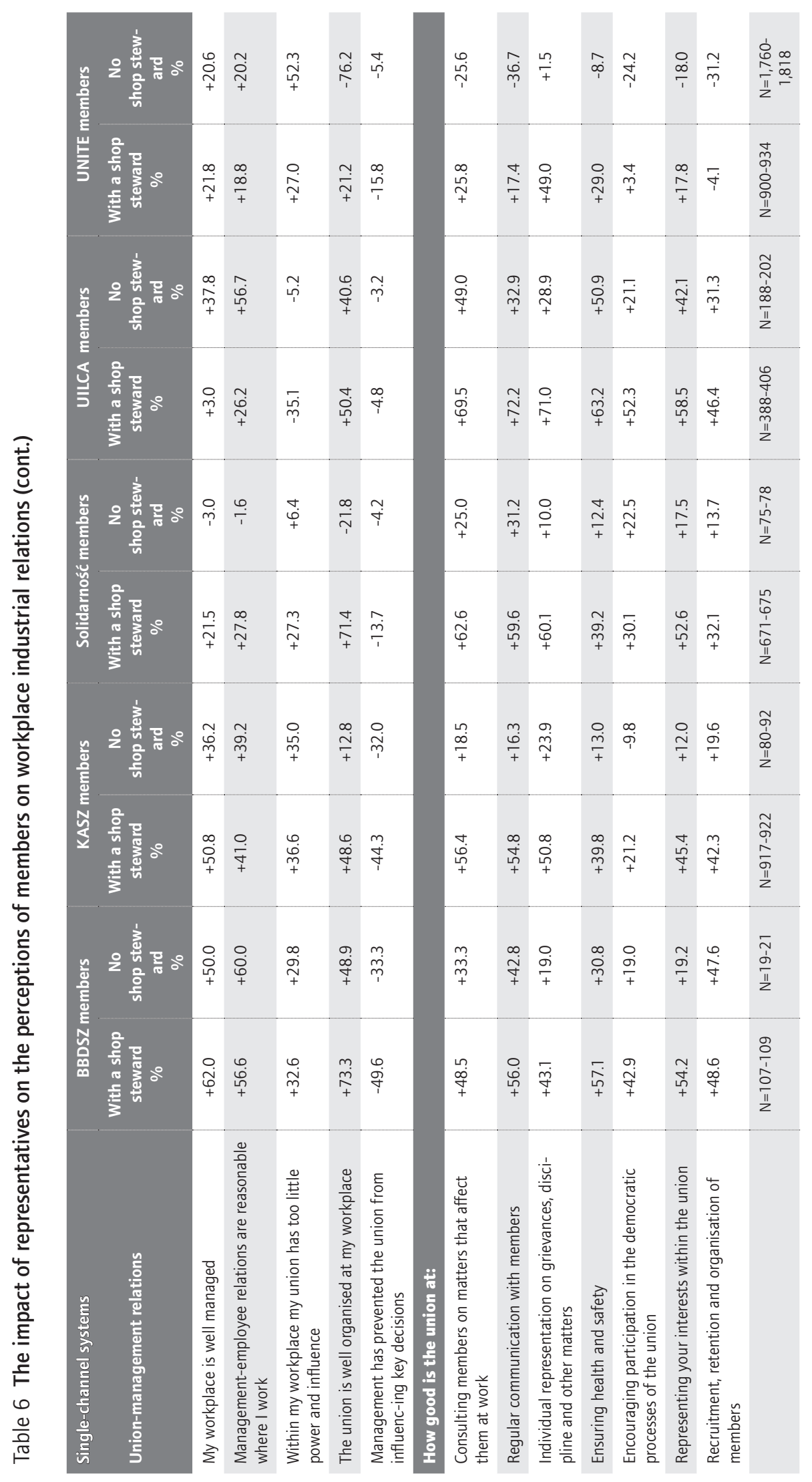




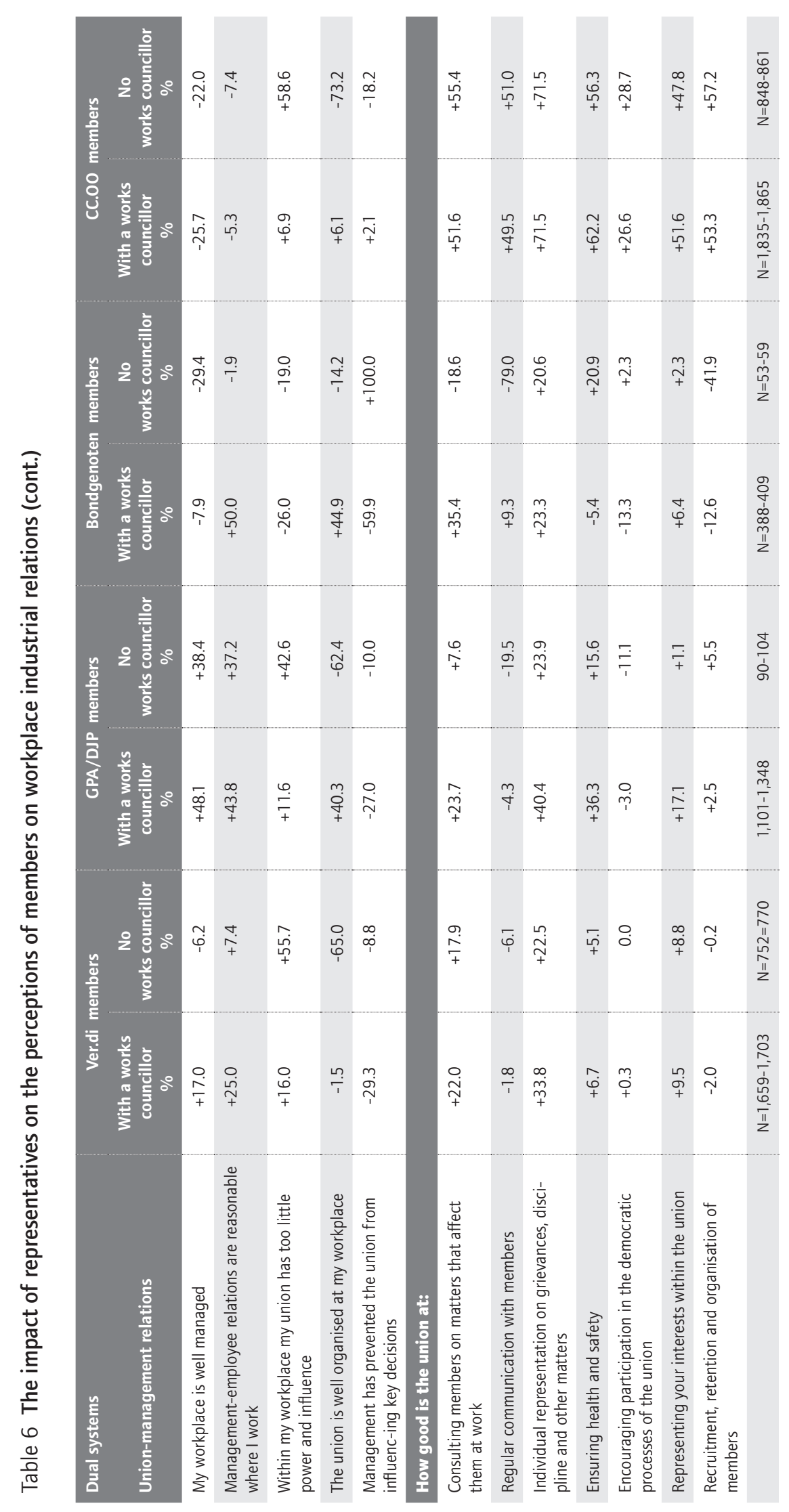


workplace representation average 69.1 percentage points, which are high compared to the differences for the other statements. Only in UILCA (9.8 percentage points), BBDSZ (24.4 percentage points) and KASZ (35.8 percentage points) were the differences in the scores between members with and without workplace representation less than 50 percentage points. From the perspective of members, union organisation is thus markedly enhanced through the presence of a workplace representative.

For both 'my workplace is well managed' and 'management-employee relations are reasonable where I work' in ten of the fourteen unions members were more positive when there was a representative present at the workplace. In five unions, four of which are Nordic (Sif, TU, NITO, HK), members with a workplace representative were more likely to cite that 'management has prevented the union from influencing key decisions' than were members without a workplace representative. ${ }^{6}$ Where members with a workplace representative were more positive than members without a workplace representative on these three issues differences were narrower than on 'the union is well organised at my workplace'. The average difference on 'my workplace is well managed' is 16.4 percentage points; on 'management-employee relations are reasonable where I work', 15.6 percentage points; and on 'management has prevented the union from influencing key decisions', 27.6 percentage points.7 These narrower differences are anticipated in so far as each of these statements refers to relations between management and workplace representatives, which are not determined solely by the actions of workplace representatives. In the majority of participating unions, however, the presence of a workplace representative was sufficient to influence unionists to take more positive views of the performance of the union.

In the eleven participating unions based in Western Europe members with workplace representation were less likely to think that 'within my workplace my union has little power and influence' than unionists within no representative present. In Western Europe members associate the presence of a workplace representative with enhanced union power and influence. In contrast, more members with a workplace representative from the three unions based in Eastern Europe (BBDSZ, KASZ, Solidarność) thought that 'within my workplace my union has little power and influence' compared to their counterparts with no union representative. While this result suggests that union influence at the workplace is more constrained in Eastern Europe than elsewhere, Hungarian and Polish unionists also thought the presence of a workplace representative limited the capacity of 'management to prevent the union from influencing key decisions' and that the union was more likely to be 'well

6. This relationship, of course, is likely to be influenced by the density of union organisation at the workplaces where the respondents were employed. There is no data, however, on this topic arising from the survey.

7. This average is distorted by the figure of 159.9 percentage points recorded for Bondgenoten, where every members without a works councillor at their place of work thought that management had prevented the union from influencing key decisions. Excluding the data for Bondgenoten reduces the average to 11.1 percentage points. 
organised at the workplace', suggesting that the constraints on union influence are mitigated. The point remains, however, that members' perceptions of union power and influence at the workplace differ in Hungary and Poland compared to those expressed in Western Europe.

The lower panel of Table 6 presents the results on the perceptions of members on tasks undertaken by the union at the workplace. Taking the tasks as they appear in Table 6 there are two on communications, two on representation, two on internal union relations and finally one on recruitment and retention. Treating the lower panel as a matrix of unions and tasks, members with a representative rated the performance of the union to be superior on 83 of the 98 cases than members without a representative. In eight of the unions operating in single channel systems (RBF, NITO, HK, BBDSZ, KASZ, Solidarność, UILCA, UNITE) members regard the performance of the union to be superior on every one of these tasks when there was a shop steward present at their workplace. Although differences between members with and without a workplace representative were small, in Sif and TU members without a representative rated the performance of the union to be superior in 'encouraging participation in the democratic processes of the union' (hereafter participation). Additionally, the same group of members in TU viewed the union to be superior at 'consulting members on matters that affect them at work' (hereafter consulting members), although both members with and without workplace representatives scored the union negatively on this issue. For the unions operating in dual systems members without a works councillor rated the performance of the union on at least one of the tasks to be superior compared to their counterparts with a works councillor and in CC.OO this situation prevailed for four of the seven tasks. ${ }^{8}$ The situation in CC.OO may result from the peculiarities in the division of labour and the constitutional relationship between works councillors and shop stewards (see Martínez Lucio 1998).

Regarding the communication tasks, only in TU and CC.OO did members without a representative rate the performance of the union on 'consulting members' superior to members with a workplace representative and in CC.OO the same situation prevailed on 'regular communication with members' (hereafter regular communication). Elsewhere members with a workplace representative rated the performance of the union to be superior on both tasks. Furthermore, in five unions (TU, NITO, HK, UNITE, Bondgenoten) on 'consulting members' and in eight unions (Sif, TU, NITO, HK, UNITE, Ver. di, GPA/DJP, Bondgenoten) on 'regular communication' the scores recorded by members without a workplace representative are negative, indicating that more members thought the performance of the union to be weak than viewed the performance as good. The average difference between the scores for members with and without a workplace representative on 'consulting members'

8. In Ver.di and GPA members without a works councillor viewed the performance of the union to be superior on 'recruitment, retention and organisation of members' whereas in Bondgenoten the performance of the union on 'participation' and 'health and safety' was superior in the absence of a works councillor. 
is 25.7 percentage points and on 'regular communication' is 26.4 percentage points. ${ }^{9}$ In other words, the presence of a workplace representative has a marked and positive impact on members' perception of the union. This point applies to the unions that operate in dual systems even though more than 20 per cent of works councillors in the sample are not unionised.

The representative tasks included in Table 6 are 'individual representation on grievances, discipline and other matters' (hereafter individual representation) and 'ensuring health and safety' (hereafter H\&S). With the single exception of CC.OO, where the scores are equal, members with a workplace representative rate the performance of unions to be superior on 'individual representation' compared to members with no representative. Furthermore, there are no negative scores recorded, indicating that even when there is no representative present at the workplace unions have implemented systems to ensure members have access to representation. In many unions, of course, full-time officers are deployed to meet the shortfall in workplace representatives. On ' $\mathrm{H} \& \mathrm{~S}$ ' it is only in Bondgenoten that members without a representative rate the performance of the union to superior than members with a representative. Elsewhere representatives have a positive effect on members' perceptions of 'H\&S'. The differences in the average scores for members with and without a representative at their workplace were narrower for both 'individual representation' (20.9 percentage points) and 'H\&S' (19.7 percentage points) compared to the communication tasks. This suggests that the presence of workplace representatives has a greater impact on the perception of members of the performance of unions on communication compared to representation tasks.

The presence of a representative also affects members' perceptions of how unions articulate workplace activities with the wider union represented in Table 6 by 'encouraging participation in the democratic processes of union' (hereafter encouraging participation) and 'representing your interests within the union' (hereafter representing interests). In all of the participating unions, members with a representative were more positive than members with no representative on 'representing interests', a situation also present in ten of the fourteen participating unions on 'encouraging participation'. It should be noted, however, that in Sif, TU, HK and GPA/DJP negative scores on 'encouraging participation' are recorded for members with and without a representative whereas in NITO, KASZ and UNITE only members without a representative record a negative score, a situation reproduced in TU and UNITE for 'representing interests'. The large number of unions recording negative scores suggests that the impact of workplace representatives is not as marked on articulating workplace activities as it is on communication and representation, a point supported by the lower average scores with and without a representative for 'encouraging participation' (17.2 percentage points) and 'represent-

9. Unions where members without a workplace representative reported a superior union performance compared to members with a workplace representative were excluded from the calculation of the average scores. This procedure is used in subsequent calculation of average scores. 
ing interests' (17.8 percentage points) than the comparable scores recorded on communications and representation tasks. The limitations of the impact of workplace representatives on the articulation of workplace activities may reflect a further influence of the decentralisation of collective bargaining. In so far as the organisational power of trade unions requires internal union democracy (Lévesque and Murray 2003:16), however, the presence of a workplace representative contributed to the maintenance or generation of organisational power.

\subsection{Comparing union performance with that of management}

Direct communication between management and employees is a key theme of much recent literature on HRM (Boxall et al. 2007; Dundon et al. 2005). Such communications can be formal or informal, may be by e-mail, workof-mouth or one-to-one meetings, may be effective as a managerial means of generating higher levels of employee commitment to the goals of the enterprise, and may lead employees to regard management as the means whereby problems at the workplace can be addressed and as the primary source of workplace information (Dundon et al. 2005; Gollan 2006; Wilkinson et al. 2013). In some circumstances direct communication from managers to employees is associated with union substitution and the bypassing of workplace representatives (Bratton 2001; Heery et al. 2004; Wells 1993). In the context of more sophisticated managerial practices intended to generate greater employee commitment, a challenge for representatives is to ensure effective communications with members, thereby ensuring that the union message and a union purpose is sustained at the workplace (Gumbrell-McCormick and Hyman 2013:152-153) and mitigating, if not avoiding, a 'crisis of workers' loyalty to their unions' (Müller-Jentsch 1988:177-178). Stage three thus examines the efficacy of management and unions on communications and related workplace issues as perceived by union members in the absence and presence of a workplace representative. The statements listed in Table 7 refer to issues where unions and management provide information and may contest the interpretation of events. Communication on these issues is thus central to securing influence.

Four points are immediately apparent from Table 7. First, and replicating the evidence presented in Table 6, for 96 of the 98 statements union members thought that the union was more effective when a workplace representative was present. Only on 'ensuring security of employment' in Sif, and 'dealing with work problems you or others may have' in Bondgenoten did members without a workplace representative think that the union performed better. Second, in 86 of the 98 cases the union performance was superior to that of management when a workplace representative was present. This number fell to 22 when no workplace representative was present. Trade unionists are thus more likely to regard the union as superior to management at the tasks listed in Table 7 when a workplace representative is present. Third, in 59 of the 98 cases the performance of the union in the presence of a workplace 


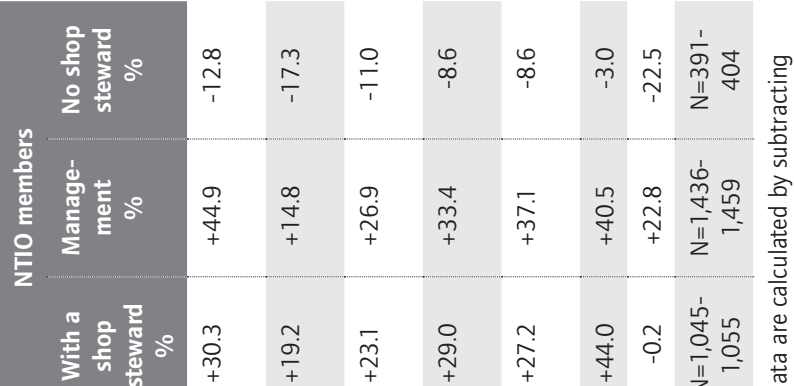

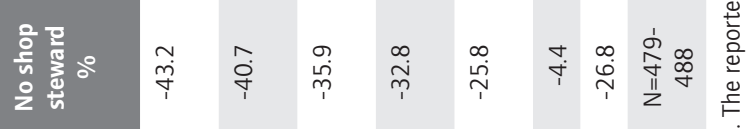

竞离

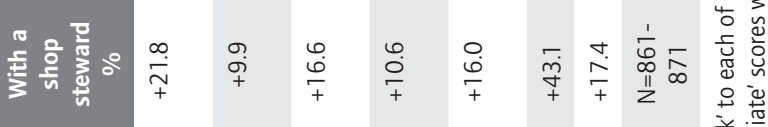

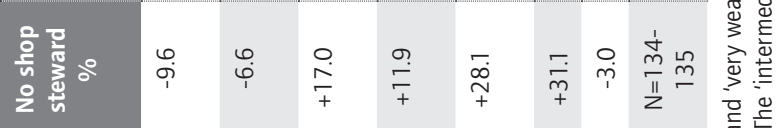

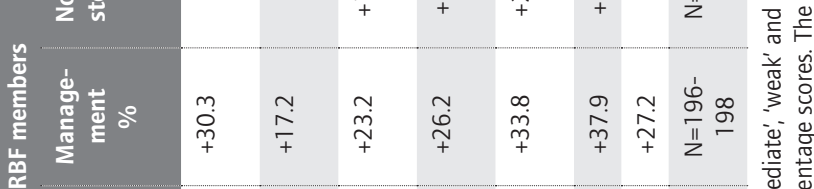

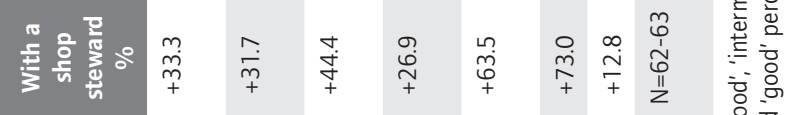

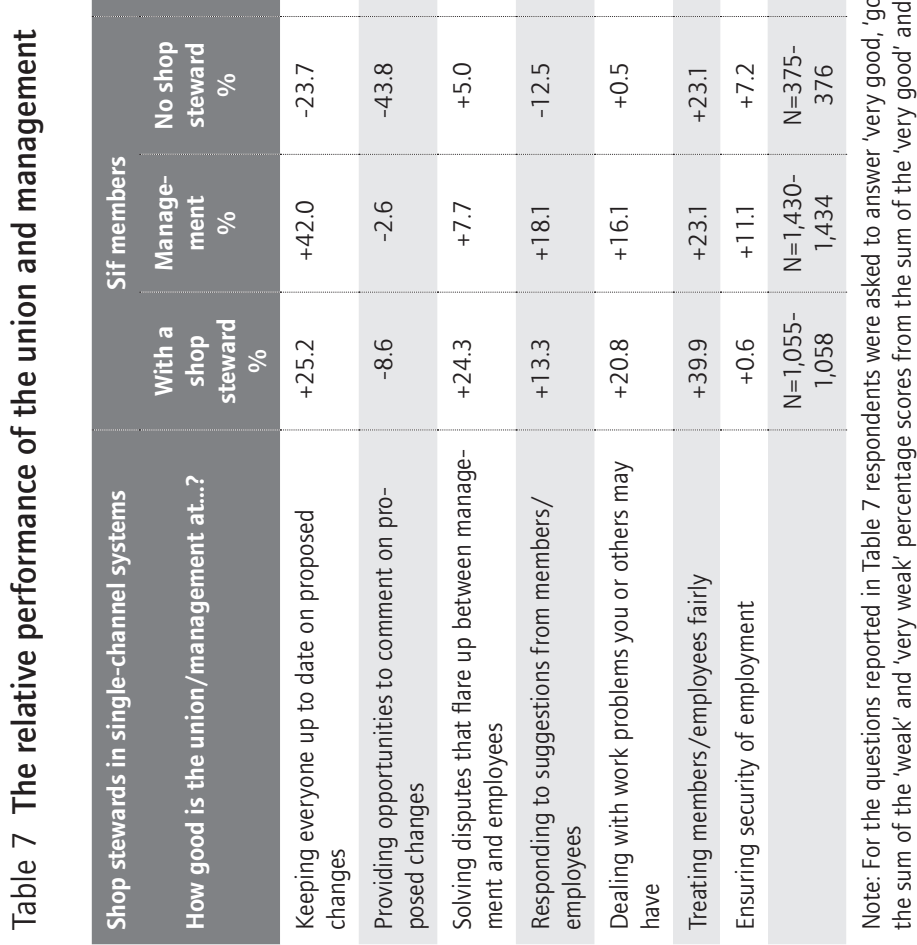

$50 \quad$ WP 2014.10 


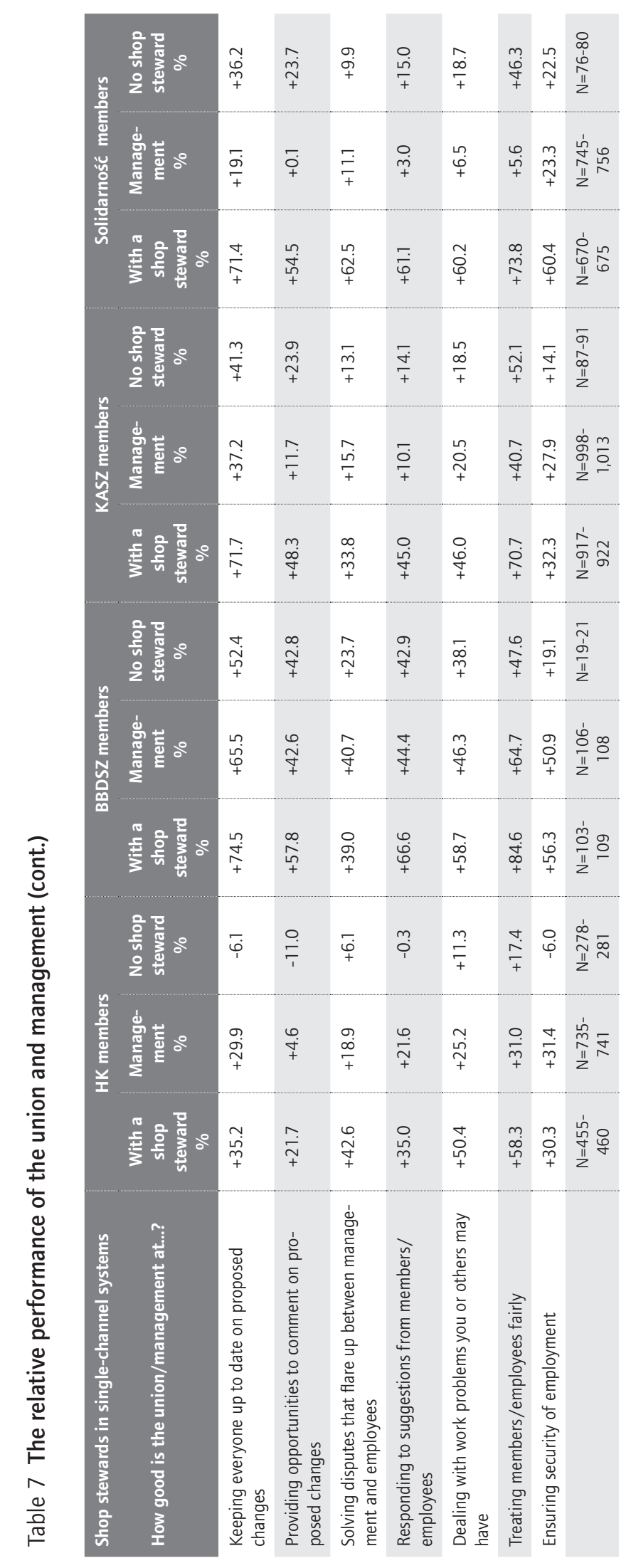




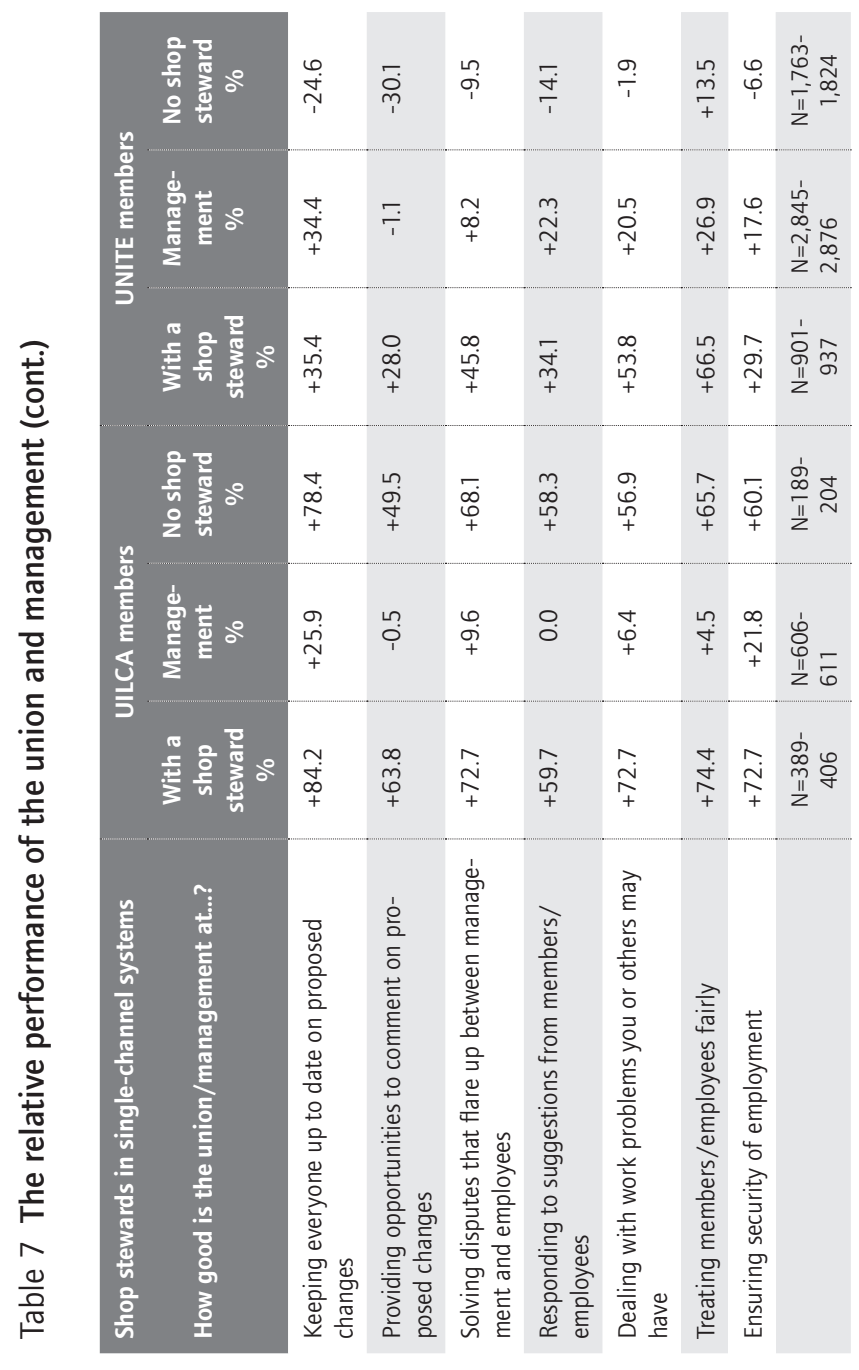

52 WP 2014.10 


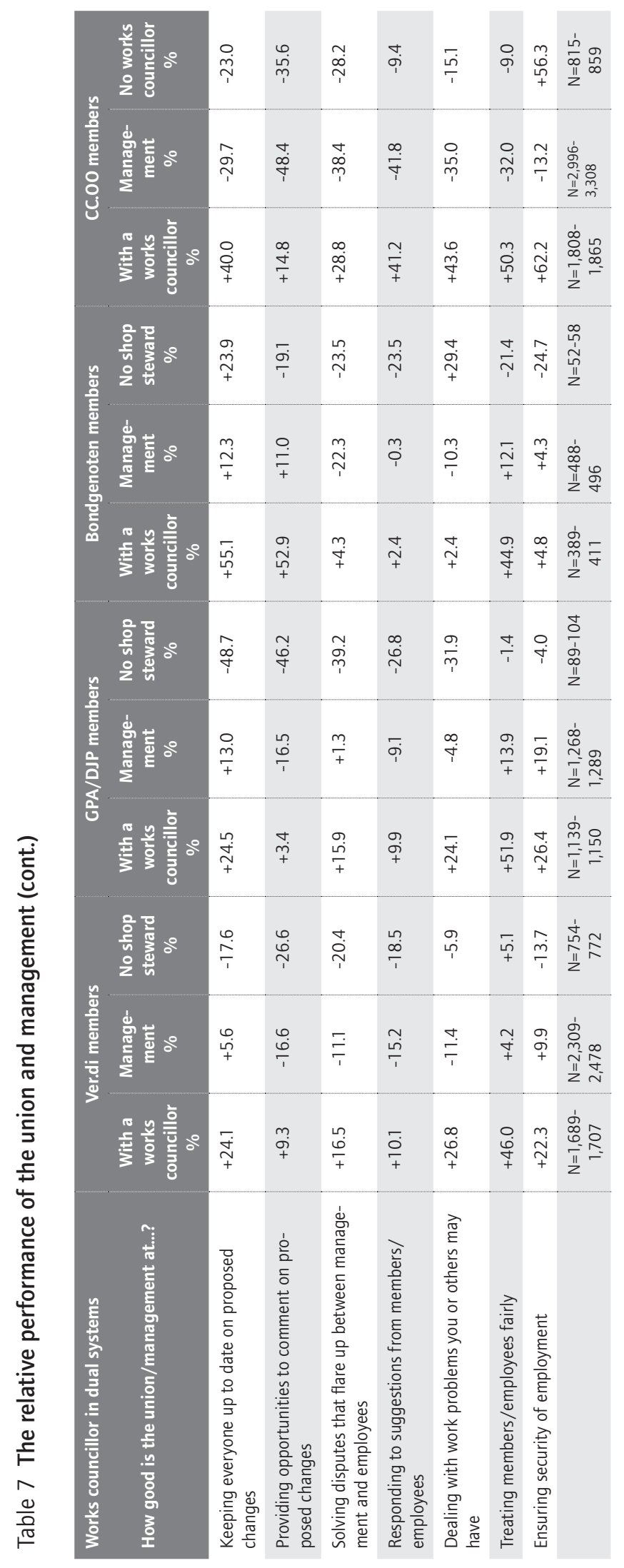


representative was superior to that of management whose performance, in turn, was superior to that of the union where no workplace representative was present. In other words, the absence of a workplace representative allowed management to gain a superior position in almost 60 per cent of the cases. Fourth, for only one case, 'dealing with problems you or others may have' in Bondgenoten, was the performance of the union in the absence of a workplace representative superior to that of the union in the presence of a workplace representative and that of management. In the majority of cases the presence of a representative is central to a positive perception of the performance of the union among members and to the perception of a superior performance of the union compared to management.

Examining the data by reference to the statements further demonstrates the impact on the perception of union performance among members of the presence of a workplace representative. The statements in Table 7 refer to issues where both the union and management may be the source of information for employees. In every union the performance of the union when a representative was present in the workplace of the member was superior to that of management on 'treating members/employees fairly'. With the single exception of NITO the same situation applies to 'dealing with work problems you or others may have'. Management outperformed the union where a workplace representative was present only in (Sif) on 'providing opportunities to comment on proposed changes' and in two unions (NITO and BBDSZ) on 'solving disputes that flare up between management and employees'. Similarly in Sif and NITO management was rated more highly than the union when a workplace representative was present for both 'keeping everyone up to date on proposed changes' and 'responding to suggestions from members/employees'. Putting aside the statement 'ensuring security of employment' in only 10 of 84 cases recorded for the remaining six statements does management outperform the union when there is a workplace representative present from the perspective of union members. Seven of these ten cases are concentrated in two unions: Sif and NITO. Irrespective of whether a single channel or a dual system is in operation, the union with a workplace representative present is generally superior in performance to management in the other twelve unions.

'Ensuring security of employment' is the only issue in Table 7 where trade unionists think that management outperforms the union when a workplace representative is present in four unions (Sif, RBF, NITO and HK). It is thus in Nordic unions that workplace representation may be inferior to management on the issues included in Table 7 , and even among Nordic unions management is superior only in a minority of cases.

In contrast, management outperformed the union when there was no workplace representative present on every issue listed in Table 7 for seven unions (Sif, RBF, TU, NITO, HK, UNITE and GPA/DJP). In only two unions (UILCA and CC.OO) did the union outperform management when there was no workplace representative present. Elsewhere management outperformed the union on six of the seven issues in BBDSZ, five issues in Ver.di and Bondgenoten, three issues in KASZ and two issues in Solidarność. In short, management is 
much more likely to outperform the union when the member is not supported by a representative at his/her workplace.

\subsection{Summary}

This section of the Working Paper has demonstrated four principal points. First, the performance of the union is superior at workplaces where representatives are present compared to workplaces where there are no representatives. Second, the union is likely to outperform management on a range of workplace tasks when a workplace representative is present, but is unlikely to do so in the absence of workplace representation. Third, a substantial minority of members with a representative present at their workplace think that there are either not enough representatives or that representatives do not adequately represent members. When these data are combined with those on the number of members who do not have a workplace representative at their place of work, a majority of members in eight of the fourteen participating unions were not content with union representation, with women members more likely to be discontented. Fourth, the three points mentioned above apply to shop stewards in single channel systems and works councillors in dual systems of representation. Although more than 20 per cent of works councillors were not unionised, there were no marked differences between the two systems of workplace representation on the core issues of this analysis. 


\section{Conclusions}

What are the implications of these findings for explanations of membership change and trade union renewal strategies? The findings presented here confirm that it is the efficacy and character of activity at the workplace that underpins trade union membership retention and suggests that the exclusion of activities at the workplace from explanations of membership change constitutes an analytical shortfall when such explanations are applied to Europe (see also Ebbinghaus et al. 2011). This point of departure raises different policy questions in circumstances of single channel and dual systems of workplace representation. Where single channel systems operate 'support' and, if collective bargaining is decentralised, 'pay' may be available through the activities of lay representatives or full-time officers. Relatively few unions have opted for servicing strategies based on the provision of 'support' through the employment of additional full-time officers. The extent of membership decline with its adverse effects on union finances precludes most unions from affording the salaries of the extra full-time officers required to provide workplace 'support' to members. Reliance on lay representatives is thus commonplace. As has been shown here, many trade unionists are employed at workplaces where there is no lay representation and women are less likely than men to work at a workplace where a lay representative is present. Furthermore, women remain under-represented among lay representatives compared to their presence among the membership in most unions (Hansen 2008; Ledwith and Colgan 2002). Similarly, in dual systems the provision of 'support' is reliant on the activities of works councillors, the distribution of which replicates that of lay representatives in single channel systems. In short, relying on workplace representatives to provide 'support' to members necessitates the extension of the coverage of such representatives, particularly in segments of the labour market where women are employed in large numbers.

The implications of these findings for union renewal are wide-ranging, particularly as for most trade unionists unionism is a phenomenon of the workplace. A reason cited by many members that leave trade unions is the inadequacy of support and representation at the workplace (Visser 2002; Jódar et al. 2009:15). In the context of deregulation and the decentralisation of bargaining it is also difficult to envisage union members either formulating and delivering a bargaining agenda or mobilising in support of such an agenda in the absence of workplace representation. A host of studies demonstrate that support from the union at the workplace is the principal reason for joining a union (Freeman and Rogers 1999: 40-43; Jørgensen et al. 1992; Waddington 
and Whitston 1997). Similarly, non-members often report an unwillingness to join a union if they perceive the union is ineffective (Dribbusch 2003). In short, the workplace representative is central to union joining and membership retention. The impact of representation on the generation of 'social capital' at the workplace is also evident. The union is perceived by members as better in communicating, articulating between workplace and wider union, and the representation of members in the presence of a workplace representative, all of which contribute to the generation of 'social capital'.

While there is no doubt that many managements have implemented more sophisticated workplace and communication practices in recent years, these have not generated a 'crisis of workers' loyalty to unions' at workplaces where representatives are present. To the contrary, members view the performance of the union to be superior to that of management in these circumstances. The opportunities for management to generate a 'crisis of workers' loyalty to unions' are more evident at workplaces where no representative is present as members are more likely to view the performance of management to be superior to that of the union. It is also the case that the presence of a workplace representative averts aspects of the 'crisis of interest aggregation' as once unions have established a workplace presence in private sector services the impact of a workplace representative is similar to that in sectors of more longstanding union organisation.

There are two further implications of these findings for union policymakers engaged in union organising campaigns. First, where unionists have adopted membership targets in organising campaigns such targets could be usefully supplemented by targets for the numbers of workplace representatives, with the objective of increasing the ratio of representatives to members. Where legally determined sliding scales specify the number of works councillors by reference to the size of the workforce increases in the ratio of representatives to members or employees are clearly more difficult to achieve. In these circumstances the appointment of more Bedrijfscontactsman (the Netherlands) and Vertrauensleute (Germany) or their equivalents elsewhere may be appropriate: that is, the appointment of union workplace representatives to supplement the legally determined cohort of works councillors. Second, there is the issue of how workplace representatives may participate in union organising campaigns. One option pursued by union policymakers is that specialist organisers be added to union full-time staff to implement organising initiatives, thereby allowing workplace representatives to pursue the representative function within the workplace. In these circumstances the paramount issues involve generating appropriate working relationships between workplace representatives and full-time organising staff, and establishing a career structure for the full-time organising staff rather than them remaining in junior positions within the union. A further policy relies on workplace representatives to conduct organising campaigns. This study demonstrates that many workplace representatives are already unable to support existing members to the standard that they require. Apart from the challenge of providing training in organising skills and requesting many workplace representatives to engage in activities that hitherto they have eschewed, this policy option raises the 
possibility that the quality of workplace representation may deteriorate from the perspective of members as workplace representatives are deployed to additional organising duties. 


\section{References}

Aidt T. and Tzannatos Z. (2008) Trade Unions, Collective Bargaining and Macroeconomic Performance, Industrial Relations Journal, 39 (4), 258-295.

Bailey J., Price R., Esders L. and McDonald P. (2010) Daggy Shirts, Daggy Slogans? Marketing Unions to Young People, Journal of Industrial Relations, 52 (1), 43-60.

Bain G. and Elsheikh F. (1976) Union Growth and the Business Cycle: An Econometric Analysis, Oxford, Blackwell.

Batstone E., Boraston I. and Frenkel S. (1977) Shop Stewards in Action, Oxford, Blackwell.

Bean R. and Holden K. (1992) Cross-national Differences in Trade Union Membership in OECD countries, Industrial Relations Journal, 23 (1), 52-59.

Behrens M. (2009) Still Married after all these Years? Union Organizing and the Role of Works Councils in German Industrial Relations, Industrial and Labor Relations Review, 62 (3), 275-293.

Benyó B., Neumann L. and Kelemen M. (2006) Employee Participation in the Hungarian Practice, in Fazekas K. and Koltay J. (eds) The Hungarian Labour Market - Review and Analysis 2005, Budapest, Institute of Economics, Hungarian Academy of Sciences, 158-174.

Blanchflower D. (2007) International Patterns of Union Membership, British Journal of Industrial Relations, 45 (1), 1-28.

Böckerman P. and Uusitalo R. (2006) Erosion of the Ghent system and Union Membership Decline: Lessons from Finland, British Journal of Industrial Relations, 44 (2), 283-303.

Boeri T., Brugiavini A. and Calmfors L. (eds) (2001) The Role of Unions in the TwentyFirst Century, Oxford, Oxford University Press.

Bohle D. and Greskovits B. (2012) Capitalist Diversity on Europe's Periphery, Ithaca, Cornell University Press.

Booth A. and Chatterji M. (1993) Reputation, Membership and Wages in an Open shop Trade Union, Oxford Economic Papers, 45 (1), 23-41.

Boxall P., Haynes P. and Freeman R. (2007) Conclusion: What Workers Say in an AngloAmerican World, in Freeman R., Boxall P. and Haynes P. (eds) What Workers Say in an Anglo-American World, New York, ILR Press, 206-220.

Bradley H. (1999) Gender and Power in the Workplace: Analysing the Impact of Economic Change, Basingstoke, Palgrave Macmillan.

Brandt G., Jacobi O. and Müller-Jentsch W. (1982) Anpassung an die Krise: Gewerkschaften in den siebziger Jahren, Frankfurt, Campus.

Bratton J. (2001) Why Workers are Reluctant Learners: The Case of the Canadian Pulp and Paper Industry, Journal of Workplace Learning, 13 (7/8), 333-343.

Briskin L. (1999) Autonomy, Diversity and Integration: Union Women's Separate Organizing in North America and Western Europe in the Context of Restructuring and Globalization, Women's Studies International Forum, 22 (5), 543-554.

Charlwood A. and Forth J. (2009) Employee Representation, in Brown W., Bryson A., Forth J. and Whitfield K. (eds) The Evolution of the Modern Workplace, Cambridge, Cambridge University Press.

Cregan C. and Johnston S. (1990) An Industrial Relations Approach to the Free Rider Problem: Young People and Trade Union Membership in the UK, British Journal of Industrial Relations, 28 (1), 84-104. 
Crouch C. (1986) The Future Prospects for Trade Unions in Western Europe, Political Quarterly, 57 (1), 5-17.

Cunnison S. and Stageman J. (1993) Feminizing the Unions, Aldershot, Avebury.

D'Art D. and Turner T. (2008) Workers and the Demand for Trade Unions in Europe: Still a Relevant Social Force?, Economic and Industrial Democracy, 29 (2), 165-191.

de Turberville S. (2007) Union Organising: A Response to Carter, Work, Employment and Society, 21 (3), 565-576.

Dølvik J.-E. and Waddington J. (2005) Can Trade Unions Meet the challenge? Unionisation and the Marketised Services, in Bosch G. and Lehndorff S. (eds) Working in the Service Sector, London, Routledge, 316-341.

Dribbusch H. (2003) Gewerkschaftliche Mitgliedergewinnung im Dienstleistungssektor, Berlin, Edition Sigma.

Dundon T., Wilkinson A., Marchington M. and Ackers P. (2005) The Management of Voice in Non-union Organizations: Managers' Perspectives, Employee Relations, 27 (3), 307-319.

Ebbinghaus B. and Visser J. (1999) When Institutions Matter: Union Growth and Decline in Western Europe, 1950-1995, European Sociological Review, 15 (2), 135-158.

Ebbinghaus B., Göbel C. and Koos S. (2009) Mitgliedschaft in Gewerkschaften. Inklusions- und Exklusionstendenzen in der Organisation von Arbeitnehmerinteressen in Europa, Arbeitspapiere 111, Mannheim, Mannheimer Zentrum für Europäische Sozialforschung.

Ebbinghaus B., Göbel C. and Koos S. (2011) Social Capital, 'Chent' and workplace contexts Matter: Comparing Union Membership in Europe, European Journal of Industrial Relations, 17 (2), 107-124.

Edwards R. and Podgursky M. (1986) The Unravelling Accord, in Edwards R., Garonna P. and Tödtling F. (eds) Unions in Crisis and Beyond, Dover, Auburn House, 15-60.

Eldridge J. (1977) Trade Unions and Bureaucratic Control, in Clarke T. and Clements L. (eds) Trade Unions under Capitalism, Glasgow, Fontana, 175-183.

Ellguth P. and Kohaut S. (2010) Tarifbindung und betriebliche Interessenvertretung: Aktuelle Ergebnisse aus dem IAB-Betreibspanel 2009, WSI Mitteilungen, (4), 204-209.

Fairbrother P. (1984) All Those in Favour: The Politics of Union Democracy, London, Pluto Press.

Fairbrother P. (1996) Workplace Trade Unionism in the State Sector, in Ackers P., Smith C. and Smith P. (eds) The New Workplace and Trade Unionism: Critical Perspectives on Work and Organisation, London, Routledge, 110-148.

Fairbrother P. (2000) Trade Unions at the Crossroads, London, Thomson Learning.

Farber H. and Western B. (2001) Accounting for the Decline of Unions in the Private Sector, 1973-1998, Journal of Labor Research, 22 (3), 459-485.

Freeman R. and Kleiner M. (1990) Employer Behaviour in the Face of Union Organizing Drives, Industrial and Labor Relations Review, 43 (4), 351-365.

Freeman R. and Rogers J. (1999) What Workers Want, Ithaca, ILR Press.

Frege C. and Kelly J. (eds) (2004) Varieties of Unionism: Strategies for Union Revitalization in a Globalizing Economy, Oxford, Oxford University Press.

Gallie D. and Rose M. (1996) Employer Policies and Trade Union Influence, in Gallie D., Penn R. and Rose M. (eds) Trade Unionism in Recession, Oxford, Oxford University Press, 33-64.

Gollan P. (2006) Editorial: Consultation and Non-union Employee Representation, Industrial Relations Journal, 37 (5), 428-437. 
Gomez R., Gunderson M. and Meltz N. (2002) Comparing Youth and Adult Desire for Unionization in Canada, British Journal of Industrial Relations, 40 (3), 521-542.

Gumbrell-McCormick R. and Hyman R. (2013) Trade Unions in Western Europe: Hard Times, Hard Choices, Oxford, Oxford University Press.

Hall P. and Soskice D. (2001) An Introduction to Varieties of Capitalism, in Hall P. and Soskice D. (eds) Varieties of Capitalism: The Institutional Foundations of Comparative Advantage, Oxford: Oxford University Press, 1-68.

Hamann K. and Martinez Lucio M. (2007) Trade Union Revitalisation in Spain, in Phelan C. (ed.) Trade Union Revitalisation, Oxford, Peter Lang, 199-212.

Hancké B. (1993) Trade Union Membership in Europe, British Journal of Industrial Relations, 31 (4), 593-614.

Hansen L-L. (2008) Leadership for Change: Making Gender Equality in the Newly Merged Danish Union 3F, Bulletin of Comparative Labour Studies, 67, 120-126.

Healy G., Bradley H. and Mukherjee N. (2004) Inspiring Activists: The Experience of Minority Ethnic Women in Trade Unions, in Healy G., Heery E., Taylor P. and Brown W. (eds) The Future of Worker Representation, Basingstoke, Palgrave MacMillan, $103-126$.

Heery E. (2002) Partnership versus Organising: Alternative Futures for British Trade Unionism, Industrial Relations Journal, 33 (1), 20-35.

Heery E., Healy G. and Taylor P. (2004) Representation at Work: Themes and Issues, in Healy G., Heery E., Taylor P. and Brown W. (eds) The Future of Worker Representation, Basingstoke, Palgrave MacMillan, 1-36.

Heery E. and Simms M. (2008) Constraints on Union Organising in the United Kingdom, Industrial Relations Journal, 39 (1), 24-42.

Hyman R. (1979) The Politics of Workplace Trade Unionism: Recent Tendencies and Some Problems for Theory, Capital and Class, (8), 54-67.

Hyman R. (1996) Is There a Case for Statutory Works Councils in Britain?, in McColgan A. (ed.) The Future of Labour Law, London, Pinter, 64-84.

Hyman R. (2004) The Future of Trade Unions, in Verma A. and Kochan T. (eds) Unions in the 21st Century: An International Perspective, Basingstoke: Palgrave MacMillan, 17-29.

Jacobi O., Keller B. and Müller-Jentsch W. (1992) Germany: Codetermining the Future, in Ferner A. and Hyman R. (eds) Industrial Relations in the New Europe, Oxford, Blackwell, 218-269.

Jarley P. and Nissen B. (2005) Unions as Social Capital: Renewal through a Return to the Logic of Mutual Aid?, Labor Studies Journal, 29 (4), 1-26.

Jódar P., Alós R. and Vidal S. (2009) Por qué los afiliados al sindicato se dan de baja. Un estudio de la desafiliación a partir de CCOO de Cataluña, Sociologia del Trabajo, 65 (1), 31-52.

Johnston A., Kornelakis A. and Rodriguez d'Acri C. (2012) Swords of Justice in an Age of Retrenchment? The Role of Trade Unions in Welfare Provision, Transfer, 18 (2), 213-224.

Jørgensen H., Lassen M., Lind J. and Madsen M. (1992) Medlemmer og Meninger, Copenhagen, LO.

Kelloway E. and Newtin T. (1996) Pre-employment Predictors of Union Attitudes: The Effects of Parental Union and Work Experiences, Canadian Journal of Behavioural Science, 28 (2), 113-120.

Kelly J. (1996) Works Councils: Union Advance or Marginalization?, in McColgan A. (ed.) The Future of Labour Law, London, Pinter, 46-63. 
Kessler I., Undy R. and Heron P. (2004) Employee Perspectives on Communication and Consultation: Findings from a Cross-national Survey, International Journal of Human Resource Management, 15 (3), 512-532.

Keune M. (2011) Decentralizing Wage Setting in Times of Crisis? The Regulation and Use of Wage-related Derogation Clauses in Seven European Countries, European Labour Law Journal, 2 (1), 86-94.

Kirton G. (2005) The Influences on Women Joining and Participating in Unions, Industrial Relations Journal, 36 (5), 386-401.

Kjellberg A. (1992) Sweden: Can the Model Survive?, in Ferner A. and Hyman R. (eds) Industrial Relations in the New Europe, Oxford, Blackwell, 88-142.

Kjellberg A. (2006) The Swedish Unemployment Insurance: Will the Ghent System Survive?, Transfer, 12 (1), 87-98.

Klandermans B. (1984) Mobilisation and Participation: Socio-psychological Expansions of Resource Mobilisation Theory, American Sociological Review, 49 (5), 583-600.

Klandermans B. (1986) Psychology and Trade Union Participation: Joining, Acting, Quitting, Journal of Occupational Psychology, 52 (3), 189-204.

Kloosterboer D. (2007) Innovative Trade Union Strategies, Amsterdam, FNV.

Korpi W. (1978) The Working Class in Welfare Capitalism, London, Routledge and Kegan Paul.

Lash S. and Urry J. (1987) The End of Organized Capitalism, Cambridge, Polity Press.

Ledwith S. and Colgan F. (2002) Tackling Gender, Diversity and Trade Union Democracy: A Worldwide Project?, in Colgan F. and Ledwith S. (eds) Gender, Diversity and Trade Unions: International Perspectives, London, Routledge, 1-27.

Lévesque C. and Murray G. (2003) Le pouvoir syndical dans l'économie mondiale : clés de lecture pour un renouveau, Revue de I'IRES, (41), 149-176.

Lévesque C. and Murray G. (2010) Understanding Union Power: Resources and Capabilities for Renewing Union Capacity, Transfer, 16 (3), 333-350.

Levine P., Flanagan C. and Gallay L. (2008) The Millennial Pendulum: A New Generation of Voters and the Prospects for a Political Realignment, Washington DC, New America Foundation.

Lind J. (2009) The End of the Ghent system as Trade Union Recruitment Machinery?, Industrial Relations Journal, 40 (6), 510-523.

Llorente Sánchez D. (2007) Explaining Union Membership of Temporary Workers in Spain: The Role of Local Representatives and Workers' Participative Potential, Industrial Relations Journal, 38 (1), 51-69.

LO (2005) LO-lønmodtagere i Tiåret 1992-2002: Konstans Eller Forandring?, LO Dokumentation, København, Landsorganisationen i Danmark.

Markovits A. (1986) The Politics of West German Trade Unions, Cambridge, Cambridge University Press.

Markovits A. and Allen C. (1984) Trade Unions and the Economic crisis: The West German Case, in Gourevitch P., Martin A., Ross G., Allen, C., Bornstein S. and Markovits A. (eds) Unions and Economic Crisis: Britain, West Germany and Sweden, London, George Allen and Unwin, 89-188.

Markowitz L. (2000) Worker Activism after Successful Union Organizing, New York, ME Sharp.

Martin A. (1985) Trade Unions in Sweden: Strategic Responses to Change and Crisis, in Gourevitch P., Martin A., Ross G., Allen C., Bornstein S. and Markovits A. (eds) Unions and Economic Crisis: Britain, West Germany and Sweden, London, George Allen and Unwin, 190-358. 
Martínez Lucio M. (1998) Spain: Regulating Employment and Social Fragmentation, in Ferner A. and Hyman R. (eds) Changing Industrial Relations in Europe, Oxford, Blackwell, 426-458.

Meardi G. (2012) Social Failures of the EU Enlargement: The Case of Workers Voting with their Feet, London, Routledge.

Milkman R. (ed.) (2000) Organizing Immigrants: The Challenge for Unions in Contemporary California, Ithaca, Cornell University Press.

Milkman R. (2007) Two Worlds of Unionism: Women and the New Labour Movement, in Cobble S. (ed.) The Sex of Class: Women Transforming American Labor, Ithaca, Cornell University Press, 63-80.

Müller-Jentsch W. (1988) Industrial Relations Theory and Trade Union Strategy, International Journal of Comparative Labour Law and Industrial Relations, 4 (3), 177-190.

Müller-Jentsch W. (1995) Germany: From Collective Voice to Co-management, in Rogers J. and Streeck W. (eds) Works Councils: Consultation, Representation and Cooperation in Industrial Relations, Chicago, University of Chicago Press, 53-78.

Nissen B. (ed.) (2002) Unions in a Globalized Environment, Armonk, N.Y., M.E. Sharpe.

Oliver D. (2010) Union Membership among Young Graduate Workers in Australia: Using the Experience Good Model to Explain the Role of Student Employment, Industrial Relations Journal, 41 (5), 505-519.

Offe C. and Weisenthal H. (1979) Two Logics of Collective Action, Political Power and Social Theory, 1 (1), 67-115.

Olsen M. (1965) The Logic of Collective Action: Public Goods and the Theory of Groups, Cambridge, MA, Harvard University Press.

Pedersini R. (2010) Trade Union Strategies to Recruit New Groups of Workers, Dublin: European Foundation for the Improvement of Living and Working Conditions.

Peetz D. (2010) Are Individualistic Attitudes Killing Collectivism?, Transfer, 16 (3), 383-398.

Perlman S. (1979 [1928]) A Theory of the Labor Movement, Philadelphia: Porcupine Press.

Purcell J. and Ahlstrand B. (1994) Human Resource Management in the Multi-Divisional Company, Oxford, Oxford University Press.

Schnabel C. (2003) Determinants of Trade Union Membership, in Addison J. and Schnabel C. (eds) International Handbook of Trade Unions, Cheltenham, Edward Elgar, $13-43$.

Schnabel C. (2013) Union Membership and Density: Some (not so) Stylized Facts and Challenges, European Journal of Industrial Relations, 19 (3), 255-272.

Schnabel C. and Wagner J. (2007) Union Density and Determinants of Union Membership in 18 EU countries: Evidence from Micro-data 2002/03, Industrial Relations Journal, 38 (1), 5-32.

Scheuer S. (2011) Union Membership Variation in Europe: A Ten-country Comparative Analysis, European Journal of Industrial Relations, 17 (1), 57-74.

Schulten T. and Müller T. (2013) A New European Interventionism? The Impact of the New European Economic Governance on Wages and Collective Bargaining, in Natali D. and Vanhercke B. (eds) (2013) Social Developments in the European Union 2012, Brussels, ETUI/OSE, 181-213.

Silver B. (2003) Forces of Labor, Cambridge, Cambridge University Press.

Sims M., Holgate J. and Heery E. (2013) Union Voices: Tactics and Tensions in UK Organising, Ithaca, ILR Press.

Sinclair D. (1995) The Importance of Sex for the Propensity to Unionise, British Journal of Industrial Relations, 33 (2), 239-252. 
Thelen K. (1991) Union of Parts, Ithaca, Cornell University Press.

Tóth A. (1997) The Invention of Works Councils in Hungary, European Journal of Industrial Relations, 3 (2), 161-182.

Traxler F. (1995) Farewell to Labour Market Associations?, in Crouch C. and Traxler F. (eds) Organized Industrial Relations in Europe, Aldershot, Avebury, 23-44.

Traxler F. (1998) Austria: Still the Country of Corporatism, in Ferner A. and Hyman R. (eds) Changing Industrial Relations in New Europe, Oxford, Blackwell, 239-261.

Traxler F., Blaschke S. and Kittel B. (2001) National Labour Relations in Internationalized Markets, Oxford, Oxford University Press.

Turner L. and Cornfield D. (2007) Labor in the Urban Battlegrounds, Ithaca, ILR Press.

Visser J. (1995) The Netherlands: From Paternalism to Representation, in Rogers J. and Streeck W. (eds) Works Councils: Consultation, Representation and Cooperation in Industrial Relations, Chicago, University of Chicago Press, 79-114.

Vandaele K. (2012) Youth Representatives' Opinions on Recruiting and Representing Young Workers: A Twofold Unsatisfied Demand?, European Journal of Industrial Relations, 18 (3), 203-218.

van de Vall M. (1970) Labor Organizations: A Macro- and Micro-Sociological Analysis on a Comparative Basis, Cambridge, Cambridge University Press.

Visser J. (2002) Why Fewer Workers Join Unions in Europe: A Social Custom Explanation of Membership Trends, British Journal of Industrial Relations, 40 (3), 403-430.

Voss K. and Sherman R. (2000) Breaking the Iron Law of Oligarchy: Union Revitalization in the American Labor Movement, American Journal of Sociology, 106 (2), 303-49.

Waddington J. (2001) Articulating Trade Union Organisation for the New Europe?, Industrial Relations Journal, 32 (5), 449-463.

Waddington J. (2006) Why Do Members Leave? The Importance of Retention to Trade Union Growth, Labor Studies Journal, 31 (3), 15-38.

Waddington J. and Whitston C. (1997) Why Do People Join Unions in a Period of Membership Decline?, British Journal of Industrial Relations, 35 (4), 515-546.

Waddington J. and Kerr A. (2002) Unions Fit for Young Workers?, Industrial Relations Journal, 33 (4), 298-315.

Walters S. (2002) Female Part-time Workers' Attitudes to Trade Unions in Britain, British Journal of Industrial Relations, 40 (1), 49-68.

Webb S. and Webb B. (1897) Industrial Democracy, London, Longman.

Wells D. (1993) Are Strong Unions Compatible with the New Model of Human Resource Management?, Relations Industrielles/Industrial Relations, 48 (1), 56-84.

Western B. (1997) Between Class and Market, Princeton: Princeton University Press.

Wilkinson A., Dundon T. and Marchinton M. (2013) Employee Involvement and Voice, in Bach S. and Edwards M. (eds) Managing Human Resources, 5th ed., Chichester, Wiley, 268-288.

Wills J. (2002) Union Futures: Building Networked Trade Unionism in the UK, London, Fabian Society.

Windmuller J. (1969) Labor Relations in the Netherlands, Ithaca, Cornell University Press.

Wright E. (2000) Working Class Power, Capitalist-class Interests and Class Compromise, American Journal of Sociology, 105 (4), 957-1002. 